\title{
TRANSFORMED CULTURE, TRANSFORMING BUILTSCAPE: EXPERIENCES FROM NIGERIA
}

\author{
C.O. OSASONA \\ Department of Architecture, Obafemi Awolowo University, Ile-Ife, Nigeria.
}

\begin{abstract}
Culture has universally been acknowledged as a conditioner of the built environment; conversely, man's living fabric is a product of his many social, economic, political, and other engagements, i.e. a product of his cultural identity. The paper examines the transformations that have taken place within the Nigerian society, from traditional times to the present, highlighting the phenomena responsible and the direct impact on the built environment. In the panoramic survey of the nation's ethnicities and landscapes, a north-south dichotomy already institutionalized in the country's socio-political structure and general psyche - is adopted. It is posited that the British colonization of Nigeria (and the consequent facilitation of Brazilian and saro influences) greatly impacted the ethnic cultures, translating into physical expressions that, to date, reverberate in contributing to the hybrid styles that characterize both the nation's vernacular and 'global style' building expressions. Sustainability, as a policy to guide physical development, is seen as being only in its infancy in the country. The paper concludes by asserting that, to the extent to which the world continues to tend toward a 'global culture', to the same extent will the generality of Nigerian culture continue to be re-defined along similar lines - and with a resultant tangible impact on its builtscape.

Keywords: Aguda, boys' quarters phenomenon, British colonization of Nigeria, cultural diffusion, Nigerian culture, Nigerian ethnic groups, north-south dichotomy, saro, traditional building, vernacular architecture.
\end{abstract}

\section{INTRODUCTION: THE 'CULTURE' PHENOMENON}

There are probably as many definitions of 'culture' as there are cultural entities, themselves. However, there are universally agreed parameters that constitute 'culture' and whose inclusion in the definition, makes it authentic. So, culture is a given framework encompassing social order and general behavior, language, mode of dress, cuisine, art, and building that generally defines a group of people, and by which they themselves would want to be identified. Consequent upon this definition is the fact that even though every social grouping has some (or all) of these yardsticks by which their identity can be determined, it is essentially the differences that exist from one group to another that clearly distinguish each group. Thus, a fundamental difference in say, language, already has implications for differences in social behavior and, progressively, overall culture between two apparently similar social groupings.

There are many cultural phenomena that readily locate a people. In today's globalized world, dress has become virtually universal (and, to a large extent westernized); as such, it would not be an appropriate cultural hallmark (except in local ethnic contexts). By the same token, body scarification - which can only be interpreted correctly locally - has limited significance and applicability as a form of cultural identification. It would, thus, appear that the phenomena that are less ephemeral (and usually more obvious for reasons of sheer physicality and/ or relative longevity of occurrence) are those that generally differentiate a people, with respect to other cultures.

Inherent in today's clearly observable globalizing trends, is the implication that the constituents of culture are liable to being progressively impacted upon. This implies that the totality of culture itself is susceptible to transformation. The most non-negotiable given, therefore, with respect to culture, is probably the fact that it is dynamic. From history (particularly in the context of colonization), it has been seen that cultural diffusion is a natural consequence of intimate sociopolitical 
interactions, with the less dominant (or subjugated) group more likely to be influenced by the other. In most parts of Africa, this has been the trend, resulting in local cultures characterized by 'hybrid' lifestyles harking back to British, French, Belgian, Dutch, or German influences, as the case may be.

Material culture, as an offshoot of 'culture', constitutes a window through which a SHRSOHmay be perceived and understood, in general terms. Thus, their artwork (essentially their visual arts) and their built environment have great potential to sociologically locate them. Specifically, the most characteristic building type (or types) of a SHSCHrepresents a microcosm of the essentials of their socio-cultural attributes, as it provides a shell for their daily interactions (person-to-person and often, person-to-deity), and serves as the locus of the dissemination of their social norms and values. At the macro scale, the built environment merely serves to extend the scope of these fundamental and culture-defining relationships, activities, and symbols, in that it extrapolates the physical setting for them to accommodate neighborhood input (at the immediate higher level) and that of the whole community, ultimately. As such, even the articulation of this archetype (vis-à-vis deployment of spaces and overall form) is seen to be an authentic cultural index - a defining image - as its very evolution is a process (made up of various milestones in the developmental continuum) and the final product, socially tested, acceptable and representative - like all other cultural phenomena.

By and large, inherent in the definition of 'culture', is the issue of sustainability. For a trend to be acknowledged as having significance, it must be manifest, distinct from what has been before, and sustained; usually, confident followership is the vehicle entrenching the phenomenon and thus guaranteeing sustainability. Fashion, a case in point, is sustainable to the extent to which it still has a sizeable followership committed to its continuance - until something else supersedes. Culture is a cumulative of sustained phenomena - and as such, has implied sustainability; as previously outlined, these elements include language, dress, cuisine, art, architecture, and even corporate mentality. However, how sustainable is culture? Even though it is certainly more enduring, however, like fashion, it is sustainable only to the point to which its adherents (or upholders) are prepared to continue to support it in its pure, un-tampered-with form. Given the possibility of intercultural transfers - and the certainty of intra-cultural mutations - retaining a particular cultural status quo indefinitely, is not only unrealistic, but not supported by human experience, to date. Sustainability in culture, therefore, appears to be what the generality of people are able to convey as being the totality of what appropriately and adequately portrays their identity, over a reasonable length of time.

\subsection{Nigerian cultures}

Oftentimes, at the level of a nation-state, it is assumed there is a prevalent social culture (or that there is a subsisting homogeneous lifestyle). Generally, such an assumption would be simplistic; in the Nigerian context, this is pronouncedly so. In Nigeria, there are over 400 ethnic groups, speaking more than 300 local dialects. Even though generally (and even within the geo-political entity itself), three major ethnic groups are frequently put forward as being 'representative', not only are they very different from each other, but there are dozens of other minority groups whose cultures are far from those typified by them. This tendency has long been adopted merely as a socio-political expedient. As such, where Nigeria is concerned, an in-depth study of socio-cultural issues would require more than the usual reduction of the ethnic agglomeration into Ibo, Hausa, and Yoruba. However, since the intention of the present work is not only to critique the nation's social culture but, more importantly, to show how the transforming impact on its social structure has translated into an altered (and still 


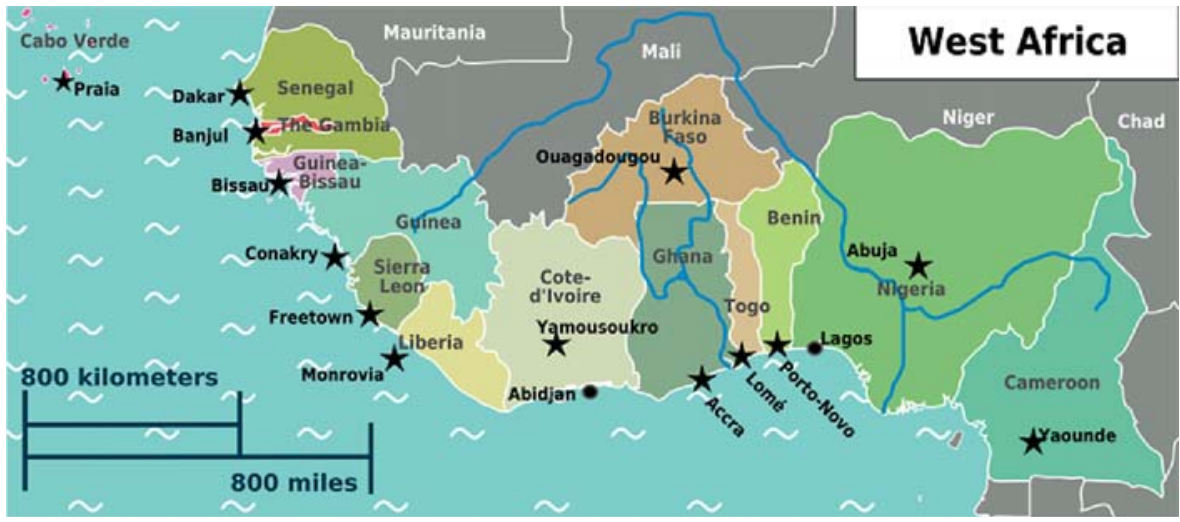

Figure 1: Map of West Africa, showing the location of Nigeria (mapsof.net/africa/static-maps/png/ west-africa-regions-map/medium-size).

altering) physical environment, only a representative overview will be attempted. A north-to-south orientation will be adopted for this cultural panorama of Nigeria (and for the general structuring of this work). This is deemed particularly convenient as the north-south dichotomy is one that appears to have been institutionalized within the country, based on colonizing influences and consequent religious (and general socio-cultural) tendencies and affiliations (Fig. 1).

\subsubsection{The core North}

In the northern parts of the country, the major ethnic groups are the Hausa and Fulani. Though, presently, they have the practice of Islam in common as the predominant religion, they are very different in their social lifestyles: traditionally, the Hausa were mostly arable farmers and bigtime traders, plying their trade by caravan journeys as far afield as Timbuktu, across the Sahara Desert. Other occupations they engaged in included weaving (of locally cultivated cotton), dyeing (both cloth and leather), and blacksmithing - all of whose products fed the Trans-Sahara trade. They lived in large, nucleated urban settlements such as Kano, Zaria, and Katsina - with equally large, outlying farmlands - and were ruled by powerful 'emirs'. They had guilds (predicated on various trades and occupations [1]), and a generally complex social system (which later became strongly conditioned by the Islamic faith [2]). Traditionally the Hausa, like most other Africans, were polygamous. A typical homestead was fenced, and comprised the zaure (or entrance hut), leading into a yard flanked by individual wives' sleeping rooms, storage and cooking spaces, and enclosures as conveniences; it was not uncommon to find an animal pen also within such a home (Fig. 2). In articulating their house-type, the Hausa basic building unit, the tubali (Fig. 3), consisted of a pear-shaped earth-and-straw mass, sun-dried and bonded with earth mortar in wall-construction (Fig. 4).

Ancillary to living spaces - and complementing a typical homestead - was the rumbu, an adobe granary, usually pot- or pitcher-shaped and covered with a readily removable thatch roof (Fig. 5); a typical household had as many rumbus as were necessary to store their grain crops of sorghum, millet, maize, beans, groundnuts, and/ or beniseed. Despite the apparent simplicity of material and form inherent in Hausa traditional architecture, it is on record that local artisans have accomplished nearfeats of engineering prowess in their ingenuity with respect to the vaulting and doming of spaces larger than the conventional associated with African traditional builtform. Using lengths of azara 


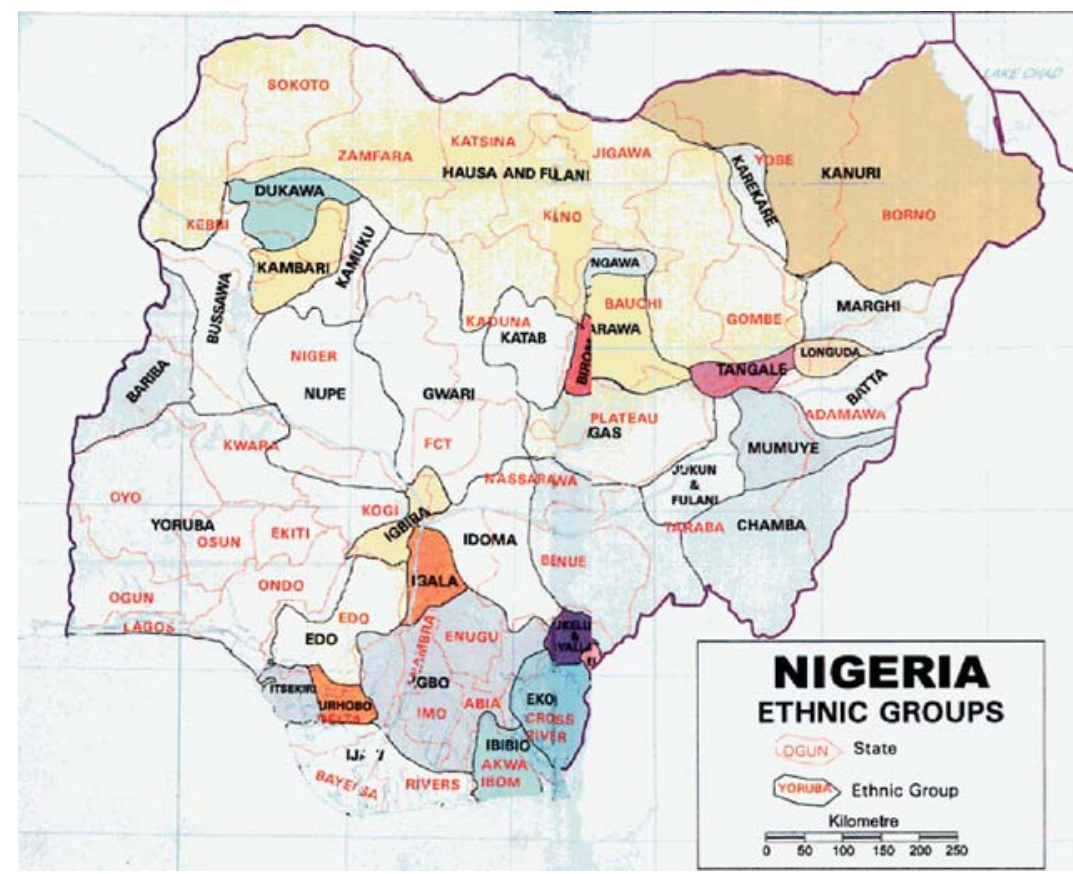

Figure 2: Nigeria: distribution of ethnic groups. Source: www.onlinenigeria.com/mapethnic.asp.

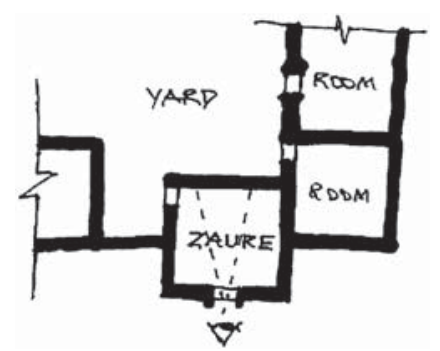

Figure 3: Common disposition of preliminary spaces in Hausa homestead. Note the skewed view from the zaure into the premises.

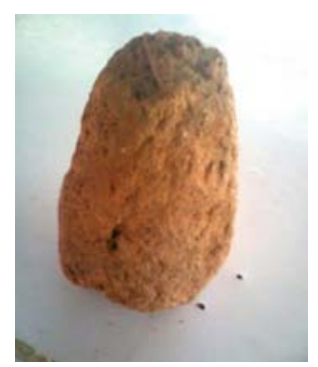

Figure 4: Tubali. The basic building unit in Hausa adobe construction. 


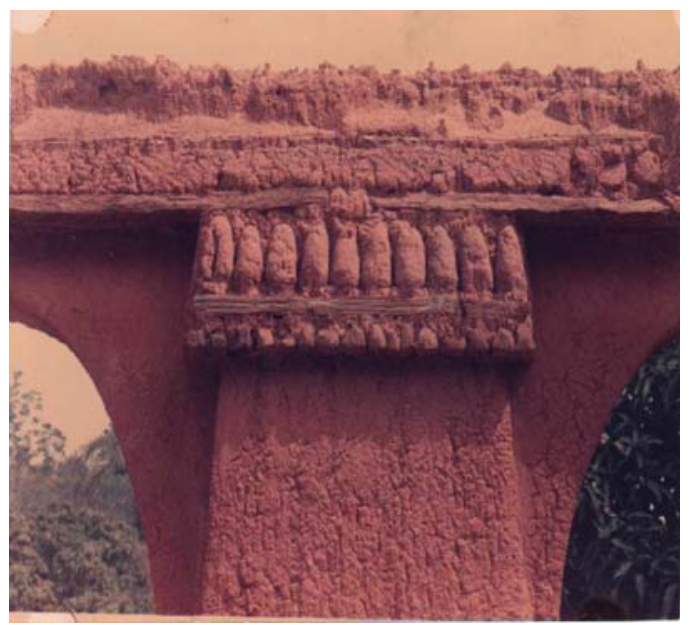

Figure 5: Hausa wall construction, showing tubali and processed earth (birgi) as mortar, reinforced with azara (1992).

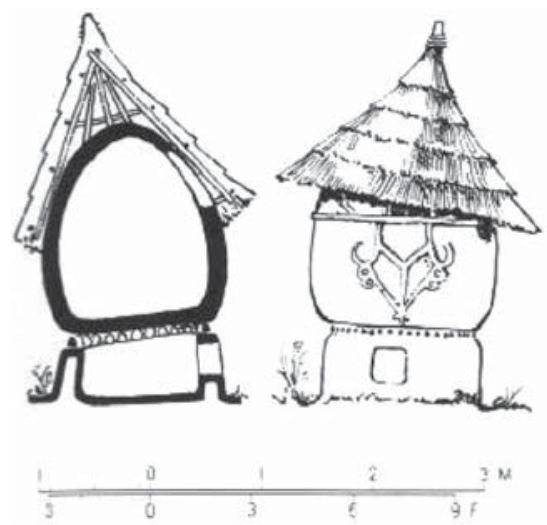

Figure 6: Section and elevation of a rumbu (Dmochowski, 1990). Surface decoration and general forms vary.

(3,000 mm-long members cut from the male oil-palm tree) embedded in swash-puddled earth (birgi), Hausa gwani (or 'master builders') have spanned spaces well in excess of $6 \mathrm{~m}$ (see Figs. 6 and 7).

For their part, traditionally, the Fulani were nomadic pastoralists whose lifestyle was greatly subjugated to the welfare of their cattle. In the past, by virtue of their occupation, they could not live in large agglomerations; instead, they lived in small groups, with social behavior guided by unwritten codes and values; every such (temporary) settlement was loosely administered by a 'head-man', the mai gari (literally, 'owner of the town'). Each homestead was extremely basic - essentially an 'A-frame', tent structure - consisting of impermanent building materials ranging from grass and sticks, through animal hides and skins, to animal-derived fabrics (such as blankets produced from sheep's wool) - or a combination of several of these (see Fig. 8). Each wife in the polygamous set-up had her own hut, living there with her children; on attainment of puberty, male children moved out 

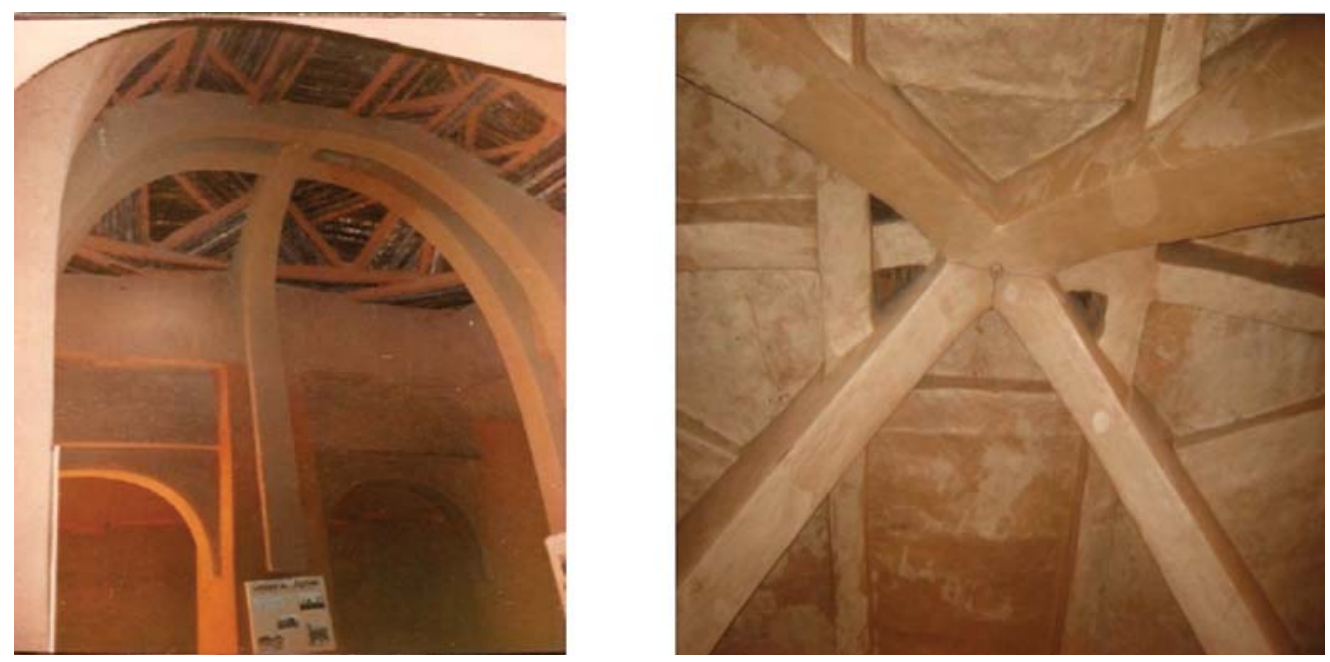

Figure 7: Traditional Hausa dome-construction. Left, azara members are left un-plastered, but selectively tinted in this house (1995); right, another building where the ribs of the dome converge; the underside of the azara is plastered over (2009).

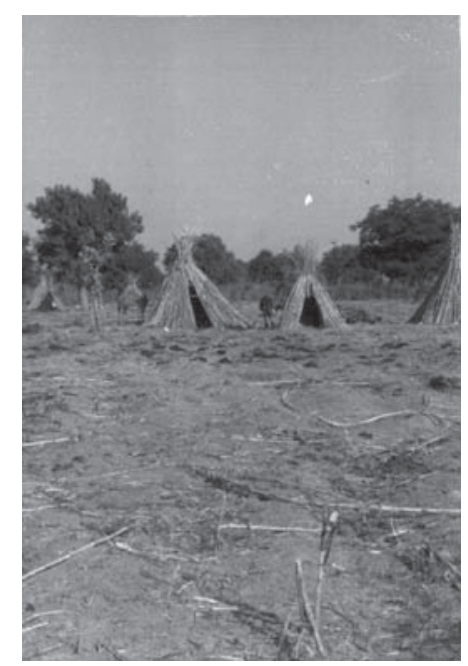

Figure 8: A Fulani settlement on the outskirts of Kano. The huts are made of stalks, with flooring of grass (1995).

into their own huts - just like the Hausa. The techniques employed in erecting these structures were predictably simple (as the underlying philosophy was ease of construction, ready de-mountability, and easy portability), and could be summarized as a lightwood-timber framework, over which the cladding materials (mentioned above) could be tied, battened, or otherwise affixed. The traditional (pastoralist) Fulani who lived out in the bush with his cattle was called Fulanin daji ('bush Fulani'). Short-term grain cropping was complementarily engaged in; as such granaries (in the same relatively impermanent materials as their houses) were a feature of their homesteads. 


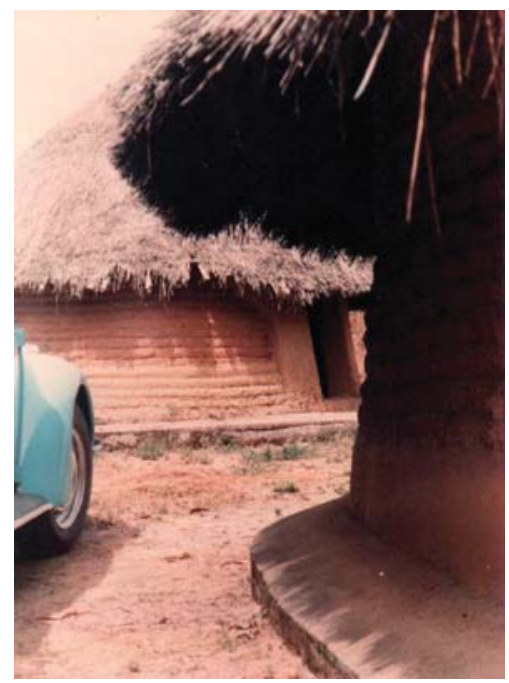

Figure 9: Tiv hut, showing thin courses giving an illusion of grooving on the wall surface (1992).

\subsubsection{The Middle Belt}

To the immediate south - in the area referred to locally as the 'Middle Belt' - there is an admixture of several ethnicities: to the north of this belt, the Hausa language is still widely spoken, while to the south (particularly toward the southwest), Yoruba is common - though neither of these languages is indigenous to the peoples of the area, as they have their own local tongues. Some of the ethnic groups here include the Idoma, Jukun, Berom, and the Tiv, around the Jos Plateau area to the east; the Gwari (or Gbagyi) and the Igbira (or Ibirra) in the center, and the Nupe to the west (see Fig. 9). Traditionally animists, these various cultures have succumbed to either Christianity or Islam (though most of them still have recourse to superstition and alternative forms of worship). As is common all over the country, the individual homestead responded organically to family size and social needs, and land was held in trust for the whole community by the traditional ruler.

These various Middle Belt cultures lived in relatively small social groupings, each essentially agrarian; such grains as maize, millet, beniseed, and sorghum were the common crops cultivated. Toward the east in this central region - specifically in the Jos area - the availability of tin, among other metals, made mining/blacksmithing an alternative local occupation. In the Nok region, stylized terracotta figure-sculpting expressed the artistic creativity of the Tiv. With respect to house-form, the Tiv built cob huts on a circle floor plan, sometimes interspersing the layers with small boulders. Even though cob construction was used, the courses were uniquely low (less than $225 \mathrm{~mm}$ high) and rounded - giving a serpentine appearance (Fig. 10). The foremost hut in a typical compound (based on size, location, and elaboration), termed ate, is the family reception and the seat of the compound head [3]. It, however, also doubled as the young men's concourse and sleeping quarters (in the event of a family celebration bringing a lot of people together).

A Tiv compound with dumbbell dispositions of ates (i.e. two sleeping huts linked together by an ate), symbolically attested to a family structure of several wives and long compound history, as each such combination signified the presence of maternal brothers sharing it [4] (see Fig. 11). Ancillary spaces such as granaries and animal pens complemented a typical homestead. Roofing was achieved using thatch, on oil-palm (or other hardy timber) rafters, with the supple stems of shrubs serving as purlins. 

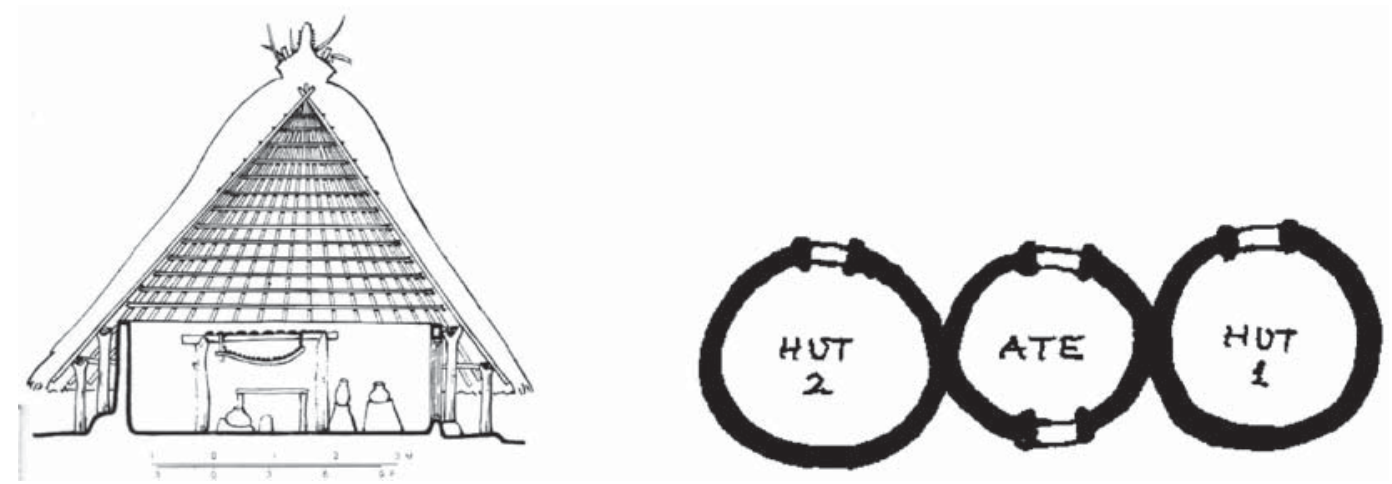

Figure 10: Left, section through a typical Tiv hut (Dmochowski, 1990); right, schematic of 'dumbbell' arrangement, signifying a maternal link between the owners of huts adjoining an ate.

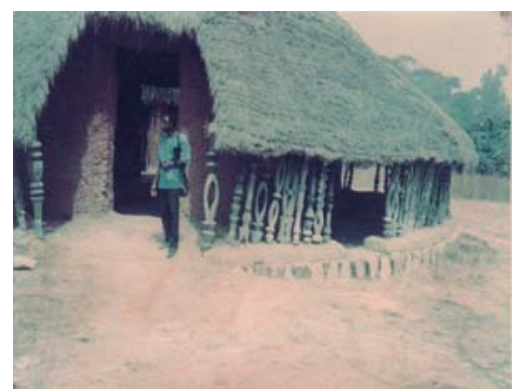

Figure 11: Nupe katamba (reproduced at the Museum of Traditional Nigerian Architecture, MOTNA, Jos). The proliferation of carved eaves supporting wooden posts is peculiar to the ruler's residence (1992).

The Nupe too, traditionally, had circular cob huts, similar in general terms to those of their Tiv counterparts. However, they were prolific decorators, specializing in heavy mural sculpting on the facades of their buildings [5] and the tessellating of doorways with ceramic platelets (giama tetengi); they used both geometric and zoomorphic motifs [6]. In addition to agrarian pursuits, the Nupe engaged in brass/bronze casting and beadwork, owing to the availability of vast local deposits [7]; fishing was also actively pursued (as the River Niger courses through their geographical territory). Characteristically, in each of these cultures, the settlement ruler's residence was very distinct: quite apart from sheer size, it invariably sported lavish ornamentation that set it apart from that of the commoners'. With the Nupe, the traditional ruler's katamba (reception hut) in addition to other decorative work, also had a framing veranda with elaborately carved timber posts holding up the low-swung eaves (Fig. 12).

\subsubsection{Southern Nigeria}

In the southeastern part of the country, the most dominant culture is that of the Igbo (or Ibo, as colonially modified). Ibo traditional settlement patterns generally depicted small, sporadic clan groupings, with administrative authority mostly vested in the head of the clan or, at best, the igwe (where the community encompassed several lineages) [8]. In traditional Ibo belief systems, the chi ('personal 


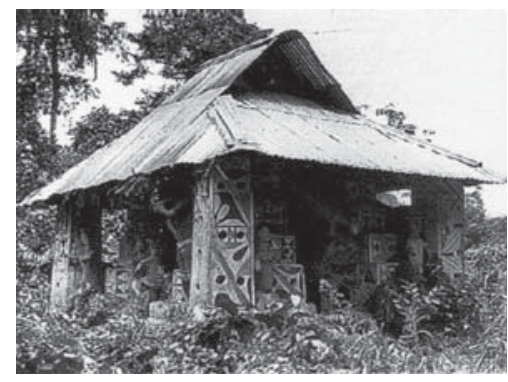

Figure 12: Mbari house, Obokwe. (Godwin and Hopwood, 2007).

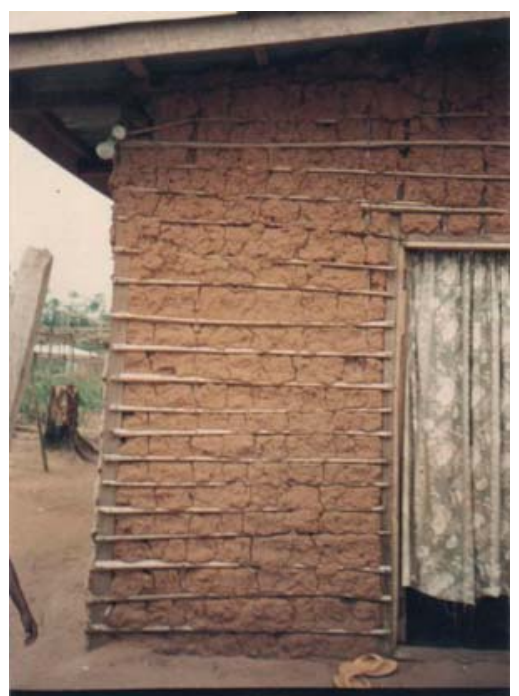

Figure 13: A wattle-and-daub house in an Ibo village in Delta State (2008).

god') is credited with being responsible for all that comes ones way - good or bad; as such, many Ibo names are pre-fixed by 'chi' (e.g. Chinedu, Chibuzor, Chimdi, and Chijioke). By the same token, the spirits of long-departed ancestors were believed to roam freely, and to be in regular intercourse with their descendants, superintending contemporary, everyday living. Homesteads were made up of discrete rectilinear cob or wattle-and-daub units, with the obi (the residence of the family head) strategically positioned for protection and general oversight roles [9]. Minimal ornamentation also featured, being essentially abstract or geometric bas-relief earth sculpting on seat/sleeping mounds, and as earth architraves framing doorways [10]. Additionally, in the event of a householder being a titled chief, his obi could be paneled with carved, open-work timber screens, the perforations of which were believed to represent 'the eyes of the ancestors' [11]. At the level of the community (and in keeping with the traditional animist approach to life), the Ibo had recourse to dibia (medicinemen), who regularly divined for them; with the Owerri Ibo, appeasement of local gods could result in the construction of a mbari house - a skeletal earth structure, lavishly decorated with mural paintings and art-in-the-round, the subject matter of which constituted tacit commentary on the community's social experiences (Figs 13 and 14). 


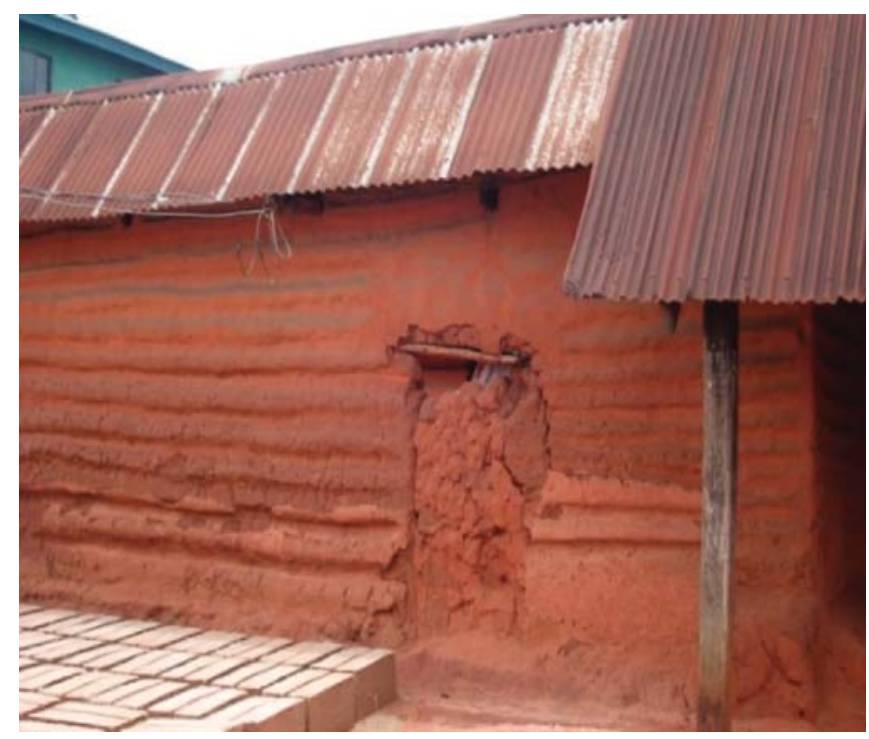

Figure 14: Horizontal fluting on a traditional-type Bini building (2009).

Traditionally, the Ibo are reputed arable farmers (growing mostly root crops) and traders. In their general disposition, they are highly sociable, assertive, and hardworking. Attesting to their sociability was the presence of men's 'clubhouses' among the Bende Ibo.

Located in the mid-western part of the country, the Bini (or Edo) culture is a relatively ancient one. One of the earliest Nigerian cultures to be actively engaged with Europeans, the Bini have a long-standing art heritage, expressed in earth, wood, bronze, copper, and ivory - a heritage they are very proud of, and which has furnished art galleries in Europe and America with exquisite exhibits, mostly illegally acquired. In their ancestral origins, they are said to have a common progenitor with the Yoruba, and in many aspects of their cultural attributes, closely resemble the Owo, a sub-division of the Yoruba. Apart from the correspondence in the basic residential unit, in the overall morphology of their towns, they are also similar. Typical Edo house-form comprised a complex of inter-related spaces, interspersed by a multiplicity of impluvia-courtyards; the largest of these courtyards (termed eghodo) was imbued with socio-cultural symbolism, over and above its purely utilitarian attributes, being regarded as the clan rallying-point for war, as well as a refuge for a family fugitive from justice. [12]. Traditional Bini architecture was characterized by building with red laterite (the locally and abundantly available soil-type). The technique was monolithic cob, plastered over with the same earth mortar, and horizontally fluted, using a curved knife or snail shell. Doors and architraves were of ornately carved timber, with braids being a very popular motif [13] (see Figs 15 and 16).

In the south-south area of Nigeria (i.e. in the creeks of the Niger Delta region), there are several ethnic groups such as the Ilaje, Ogoni, and Ijaw. These are cultures whose geographic terrain is mostly swamp, and who make their living from fishing and other water-related enterprises. The Ijaw are notable among this group, with their members scattered over Lagos, Ondo, Bayelsa, Delta, and Rivers States. Traditionally, they lived simple lives predicated on fishing for shrimp, fish, and other marine life. Correspondingly, their villages were small and physically unpretentious. Because of their marshland setting, the Ijaw devised a house-type comprising lightweight cane-based walling, on a platform of bamboo, tied together, with the whole structure supported by timber piles. 


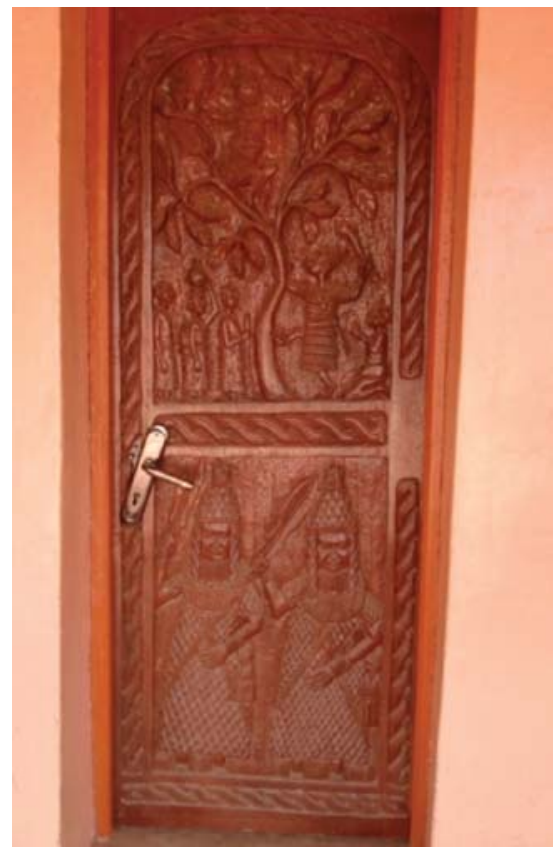

Figure 15: Bini carved door, featuring two figures of monarchs, and the popular braid motif (2009).

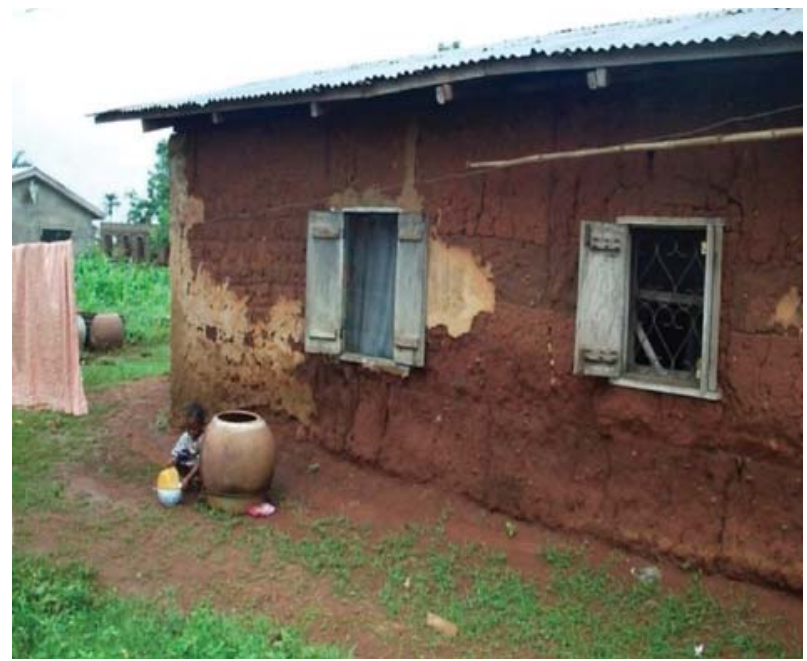

Figure 16: Though not strictly 'traditional', this house shows a combination of adobe, extreme left, and cob construction techniques. Iwesi village, Ijebu-Ode (2007).

Raffia-palm fronds were used as roof-cladding, and also woven into mats for use in bathing and other enclosures. Also as a result of this marshland setting, much of the folklore and traditional belief systems hinged on the activities of mermaids and other water apparitions. These south-south communities were active participants (and unfortunate victims) of the 16th-18th century obnoxious slave trade. 


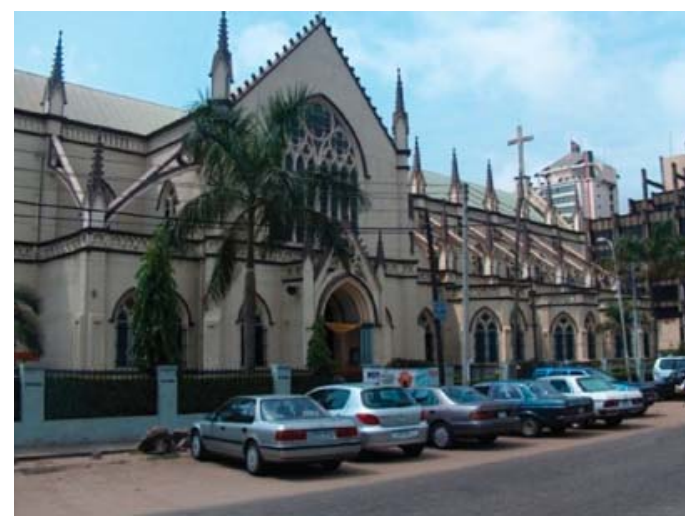

Figure 17: Holy Cross Cathedral (Lagos), completed in 1934; a colonial church (2006).

The southwest is peopled by the Yoruba, an ethnic group that generally traces its origins to Oduduwa, and the ancient city of Ile-Ife. Their settlements are located within the Equatorial Forest belt, with an abundance of large-girth deciduous and hardy trees, and excellent building laterite. Traditionally, they lived in large urban aggregations, and thus - unlike the Ibo - were able to operate a centralized system of socio-political administration. A typical Yoruba town had a clustered, radial configuration, analogous to a wheel: major circulation routes radiating from the residence of the traditional ruler (the oba), constituted 'spokes' of the wheel, with the palace as the hub; invariably, there was a major market close to the palace - and for that reason, termed oja oba ('the king's market' [14]). The $o b a$ wielded social, political, and religious power over his subjects. Though not totalitarian in his administrative capacity (as he was guided in governance by a team of 'king-makers' and the chief priests of the various traditional deities, who counseled him throughout his tenure), he nevertheless, was held in very high esteem. This larger-than-life image was summed up in the popular traditional appellation kabiyesi ('k'a bi e si' - no-one dare question him; alternatively, 'ka bi o e si' - no-one dare question you). Though agrarian in occupation, the Yoruba were also traders in locally woven-and-dyed cloth; in addition, they engaged in beadwork, calabash-carving, and other crafts [15]. Specifically, Ile-Ife has become world-famous for its naturalistic terracotta and bronze heads, first brought to the limelight by Froebenius when he visited the town in 1910 [16]. Reputed to be soft-spoken and generally easy-going, the Yoruba traditionally prided themselves in resolving issues diplomatically - rather than resorting to the use of force of arms. This, however, is not to say there were no wars in Yoruba history; on the contrary. With respect to architecture, the prevalent house-type was a rectilinear-shaped arrangement of living spaces, punctured by one or more impluvium courtyards - reminiscent of the Bini typology - and which served not only as climateconditioners and rain-water collection points, but also as rallying spaces for family interactions. Construction methods entailed adobe (featuring the use of pre-molded, rectangular, sun-dried units) or cob (in which the earth was applied in courses, each between 450 and $600 \mathrm{~mm}$ high - Fig. 17). Similar to other traditional Nigerian cultures, the Yoruba were animists but had an over-riding belief in a supreme being called olodumare.

\section{AGENTS OF TRANSFORMATION}

A state of equilibrium is lost when an impacting force succeeds in overcoming the prevailing inertia. For many African cultures, the choice to drastically change socio-culturally (i.e. to 'modernize'), 
was not voluntary; most had no choice but to surrender their traditional ways to the compelling circumstances of colonization.

In Nigeria, the major culture-impacting force was British colonization; this affected both the northern and southern regions of the country - though to varying degrees. Another phenomenon, localized essentially to the north, were Arabic Islamizing forces from North Africa that successfully traversed the Sahara Desert, and penetrated the country. Each one of these two major groups of influences progressively and irreversibly affected the indigenous cultures they came in contact with, in the various parts of the country.

Prior to the advent of the British to Nigeria, the Portuguese had held sway, commercially, on the West African coast. They had found their dealings with Ghana, the 'Gold Coast', particularly lucrative (from where they exploited the abundant local deposits of gold, and later slaves), leading to the establishment of Portuguese forts and castles along the coast, as early as the 15th century [17]. Apart from Badagry in the west, Benin and some places in the delta and far eastern regions of the coastline, the Portuguese legacy (and overall impact) in Nigeria was relatively minimal. By the 17 th century, the British were providing stiff competition - particularly in the infamous slave trade - and by the 19th century (having spearheaded the abolition of the slave trade in 1807) led European intercourse with the West Africa sub-region.

\subsection{The impact of British colonization}

The colonization of Nigeria by the British affected the subjugated ethnicities profoundly, as virtually every facet of their daily lives was touched upon - either subtly or pointedly. Certainly, politically and administratively, the British were unapologetic in ensuring their colonies were annexed to the Crown, as structures were put in place guaranteeing the pleasure of far-away England. Hence, in Nigeria, raw materials to feed the Industrial Revolution (and later, the First and Second World Wars) were vigorously exploited. These included cotton, tin, and groundnuts (peanuts) in the north and Middle Belt; timber and rubber in the mid-west; cocoa in the west (originally brought by the Portuguese from the Americas); coal in the east, and palm oil in the coastal regions. Later - and to displace all other products in economic viability - came the discovery and exploitation of crude oil.

To serve their colonizing interests in Nigeria, it was expedient for the British to register more than a fleeting presence. They needed to be able to verbally communicate with their subjects; to be manifestly in control (administratively and politically); to be able to exploit, process up to a point and store raw materials; to be able to move with ease around their colony, and to be physically resident to superintend all these (and other) activities. As such, the English language was taught and became the lingua franca. Schools were instituted to disseminate Western education and, hand-in-hand with this, the Christian religion was propagated (as, invariably, missionaries constituted the teaching staff and ensured the curriculum was Bible-based). Part of the 'education' that came with colonization was grooming in 'court manners', covering dress, table manners, and general etiquette. A common feature of the colonial occupation was the conferment of English names on the indigenes - either to replace local ones that were found 'unpronounceable', or in the wake of actual christening ceremonies, after conversion to Christianity. Missionaries used not only the platform of formal education (as distinct from the informal, oral-tradition-based indigenous approaches hitherto in place) to spread the gospel; their healthcare delivery missions of mercy were also a popular vehicle for evangelization.

More socio-culturally significant, however, was the actual administrative structure the colonialists put in place, particularly after 1914 (when the Northern and Southern Protectorates were amalgamated): in general terms, the country was administered, regionally, by 'indirect rule' - a 


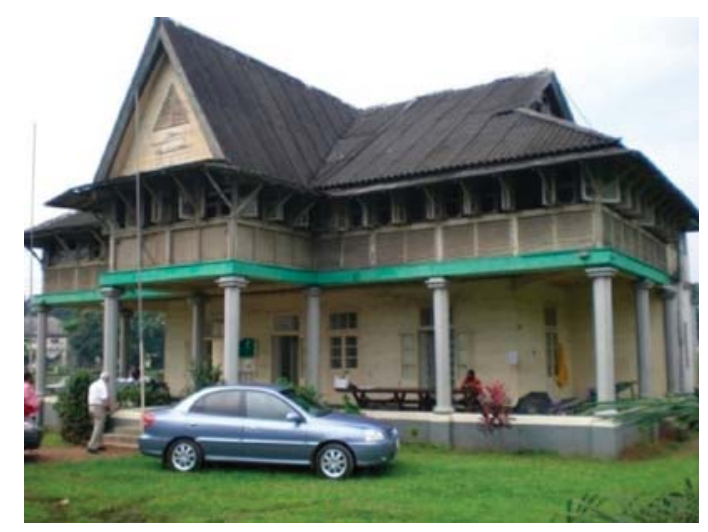

Figure 18: Jaekel House in the defunct Nigerian Railway Corporation premises. Ebute Metta, Lagos (2007).

political framework enabling them to delegate immediate (but limited) socio-political authority to recognized ethnic leaders, who thus became their liaisons with the local populace. District Officers (DOs), were appointed - each to work with local rulers and generally oversee the affairs of whichever of the four regions (northern, western, mid-western, and eastern) they were assigned to. This system of administration worked commendably well among most ethnicities in the country (particularly among the Yoruba and Hausa who lived in urban agglomerations, under the authority of a prestigious monarchy or emir-ship, respectively). However, with others - particularly the Ibo who lived in scattered, de-centralized groupings - it was sometimes disastrous; nevertheless, the colonial presence (and inherent authority) was uncompromisingly impressed upon the citizenry - sometimes by force of arms.

Before Nigeria came under British colonial administrators, the traditional builtscape had essentially featured residential architecture, with limited examples of community buildings (such as shrines and clubhouses) and ancillary structures like granaries. However, the colonialists introduced architectural pluralism: the British had a typology for virtually every function - despite the initial drawback of all such typologies wearing a residential, domestic aspect. Thus, there were schools, hospitals, banks, churches, courthouses, prisons, offices, factories, and warehouses, among others (Fig. 18).

Distinguishing characteristics of British colonial architecture included the use of steep, hipped roofs, in the North European tradition (and with shingles or cup-tiles), columned and massive masonry structuring, extensive verandas and, initially, the integration of fireplaces and chimneys. Lofty ceiling heights - with timber-paneled profiling - were also characteristic. Before the introduction of the extensive use of glass, windows were either timber panel shutters or timber-slatted jalousies, progressively with fan-lights; these sequentially gave way to the sash or multi-paned glass casement window, closer to Nigeria's independence [18]. The merchant class was quite at home combining living and trading activities; thus, their accommodation was an iron-framed, timber structure, featuring living quarters on the first floor, over warehousing and other business-activity spaces, on the ground floor (see Fig. 19). On the other hand, with the administrators, there was a sharp dichotomy: work was work - to be clearly differentiated from the home environment; so, there was a distinct location for the residence, and an equally un-ambiguous organization of spatial components [19]. 

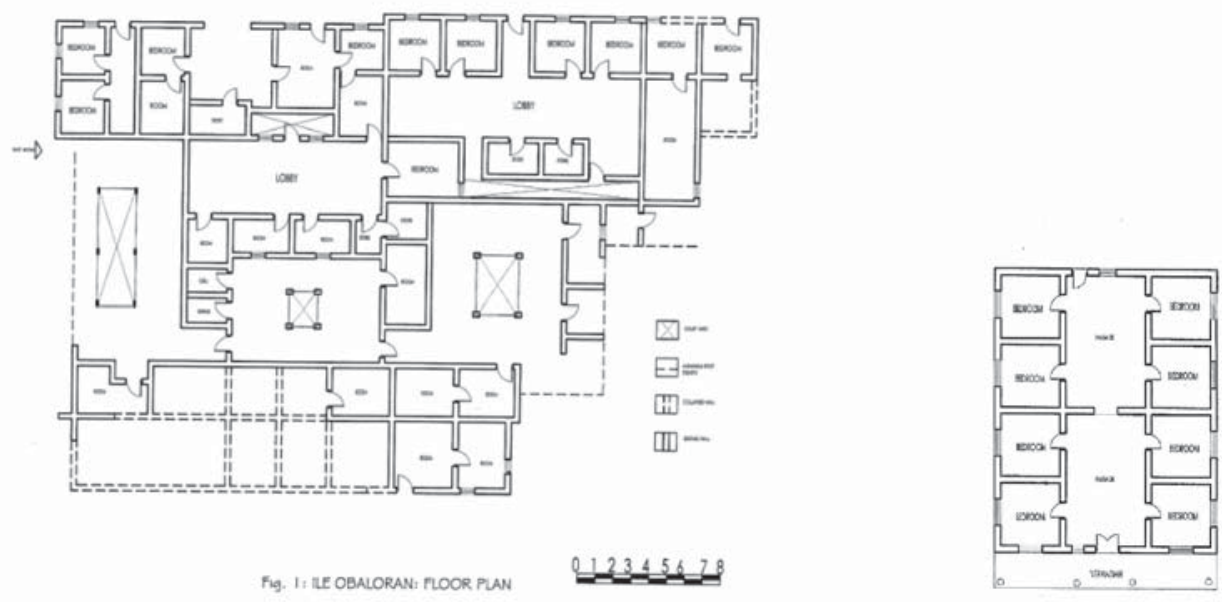

Figure 19: Left, Ile Obaloran, typifying the rambling, multi-impluvium-courtyard traditional Yoruba house. Right, Ile Aguro, an example of a vernacular articulation of space, based on Afro-Brazilian precedents. Both houses are in Ile-Ife (1999).

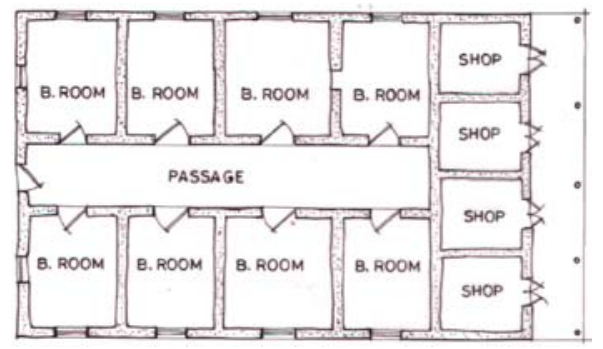

Figure 20: Ile Alikin, Ile-Ife. Another vernacular expression portraying the typical 'living-and-selling' disposition of Yoruba homes (1999).

The British colonial residential environment was characterized by low-density development, featuring one- or two-storey buildings on ample plots of land; each property was separated from others by herbaceous borders and, later, dwarf walls. Each residence had well-kept lawns and flowerbeds. Such residential areas (termed European Residential Areas, ERAs) were well-serviced by a network of tarred or cobbled roads, piped water, electricity, sewers, and community facilities for recreation and worship. Each colonial house had a 'boys' quarters' (accommodation for domestic servants) within its spacious grounds; these were invariably detached, in direct response to the need to keep the natives at arm's length - both as a sanitation and social expedient, from the colonial point of view (see Figs 20 and 21).

Apart from their own direct impact on both the cultural and physical landscapes, the British facilitated other influences coming to bear on Nigeria. Essentially, these were the effects of the repatriation of freed slaves from Bahia in Brazil, Cuba, and other Latin American states, as well as those who had initially been taken to Sierra Leone, after being released from slavery by the British. 


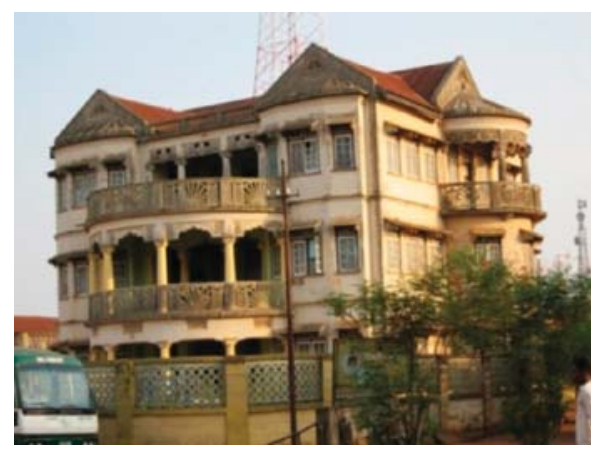

Figure 21: Kekere-Owo House, Ijebu-Ode. Built in the Afro-Brazilian style, in the early 1940s (2010).

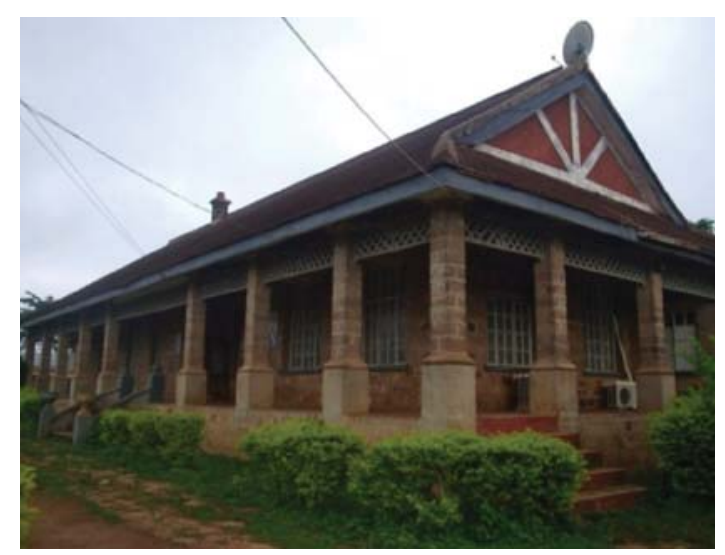

Figure 22: Colonial building, sporting timber fretwork, Sierra Leonean-style. Notice chimney, background left (Modakeke, Ile-Ife). Formerly, District Officer's residence (2006).

\subsection{Colonially facilitated influences}

Repatriates from Brazil, Cuba, and other Latin American countries (commonly called emancipados), were settled by the British in various parts of West Africa. Those specifically from Bahia were essentially Muslims, and had actually been 'deported' because of their religious intransigence [20]; they were mostly re-settled in former Dahomey (now Republic of Benin). However, repatriates from other parts of Latin America were taken to Lagos. These were mostly Christians - invariably Catholic - having imbibed this form of worship, among other things, during their sojourn in the Americas. They were referred to as aguda, by the local populace, the word being colloquial Yoruba for Catholic. They were essentially skilled craftsmen, specializing in the highly ornate Hispano-Portuguese brand of architecture popularized by much of the Brazilian building culture. Fired bricks and cementmortar were the materials favored by this building style.

Apart from being generally elaborate in detail, their architecture was characterized by multi-storey construction, complex roof configurations (featuring attics and the use of dormer windows); balconies and staircases with ornate newels and balustrades; decorative highlighting of quoins, plinths and columns; relief murals; a detaching of conveniences (as outhouses), and the use of an exaggerated, centrally located, double-loaded corridor (termed passagio in the original Portuguese archetypal antecedent) Figs. 22-24. 


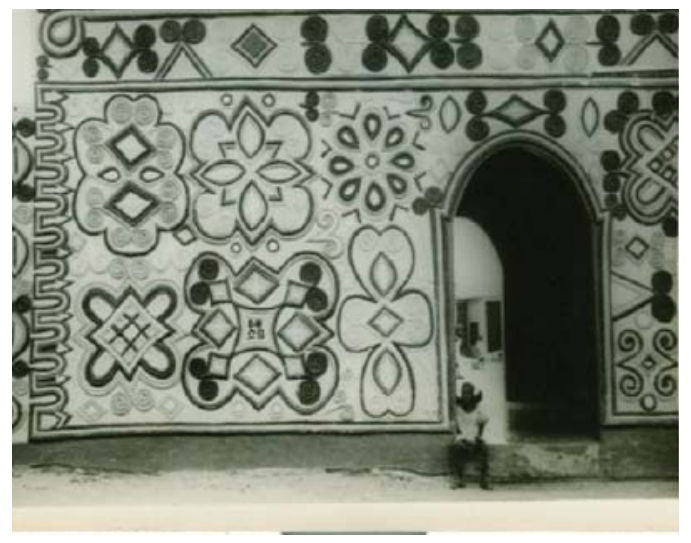

Figure 23: The palace of the Emir of Zaria. Mural sculpting using typical arabesque, geometric, and other abstract motifs (1991).

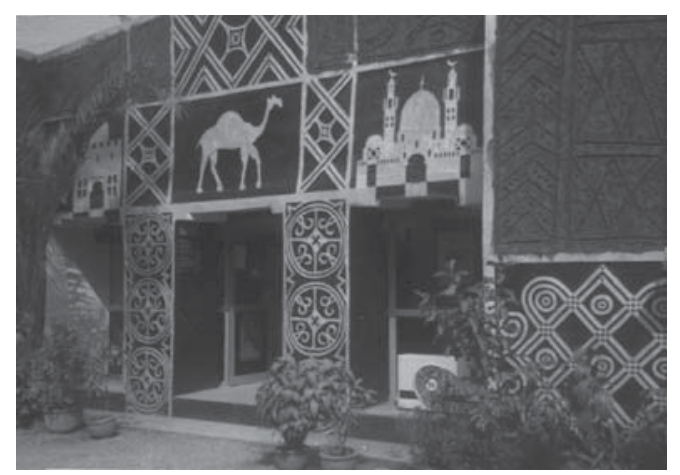

Figure 24: Façade of British Council building, Kano. Camel and mosque motif, combined with abstract shapes, somewhat atypical (1995).

The British established Freetown in Sierra Leone, in 1807, as a settlement for former slaves from the United Kingdom. Similar to the case of their emancipado counterparts, their general culture was reminiscent of the totality of their experiences in Britain. Hence, they instituted a building culture featuring timber-framed-and-boarded houses, single- or two-storey, usually with an en-framing veranda. Attics, too, were not uncommon. The use of carved fascias and timber fretwork at eaves was characteristic [21]. Some Sierra Leonean repatriates who, apparently, were able to trace their ancestry back to Nigeria, eventually found their way to Lagos - a move again facilitated by the British. Again similar to the experience of the Latin American repatriates in Lagos, they were colloquially called saro - probably the corrupted form of 'Sierra Leone'.

They were astute businessmen, popularizing the two-storey mixed-use archetype (adopted and adapted by British merchants), expressed either in wood or fired brick. Also, carved fascia boards and fretwork were regular features. Cumulatively, the saro architectural model essentially harked back to British building traditions Fig. 25. 


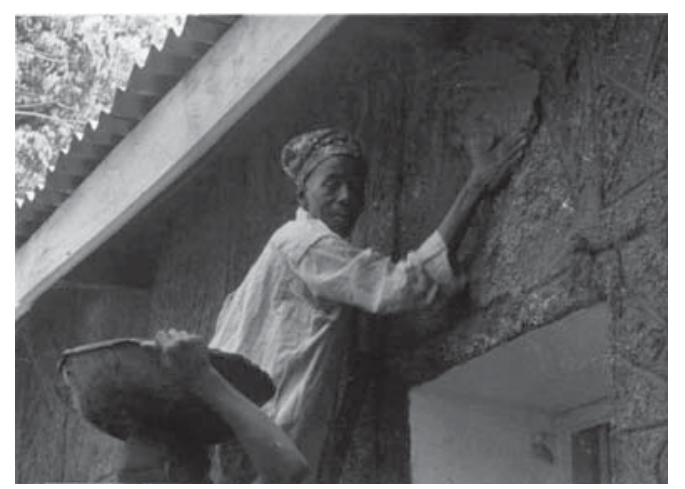

Figure 25: Traditional Hausa craftsman (with apprentice) working on the decorative mural at the back of the building.

\subsection{The Arabic-Islamic influence}

While the Europeans exploited the sea-route to Nigeria, the Arabic influence overran the northern part of the country from across the Sahara Desert. Apart from the trade prospects and relationships that had existed long before the advent of the Europeans to the south, the incident of the jihad - the Islamic 'holy war' - waged by Uthman Dan Fodio and his disciples early in the 19th century, was the single dominant phenomenon responsible for entrenching the Islamic culture in northern Nigeria. With the institutionalizing of Islam, came other cultural institutions like emir-ship, koranic schools, and purdah.

Northern emirs were extremely powerful. They wielded religious as well as secular authority, and were greatly esteemed and feared. The Islamic (socio-religious) penal code, the sharia, was strictly administered by them, with its dictates being fastidiously interpreted by local Muslim clerics (imams). (This prevailing deference to them was the basis for the later British administration of the northern region, indirectly, through local emirs). Koranic schools were set up to train children in knowledge of the Koran, and generally instill in them the tenets of the Islamic religion. Purdah was a marriage exigency established to protect women from unwholesome male attention. It was, initially, more a feature of wealthy Muslim homes, as it prescribed seclusion (or at best, exclusive, veiled and chaperoned outings) for the married woman; this could more readily happen where the man could afford domestic staff who could gap-fill for the woman, in the discharge of some of her many household duties. Even where purdah was not enforced, Islamic dictates of separation of the sexes and restriction of visual and general access to the womenfolk of a household, conferred a status of the family 'security post' on the zaure (see Fig. 2). This was in the sense that, from his vantage location within it, the household head could screen visitors, ensuring those of doubtful credentials never went beyond it [22].

Archetypically, Islam left its mark on the north; the major new entrant on the landscape was the mosque, typified (in its most celebrated form) by arches, colonnades, minarets, and at least one dome. Progressively, from this spiritually and physically dominant archetype, certain elements became characteristic features of the building culture of northern Nigeria: arches and applied mural decoration became commonplace. Architectural decoration reminiscent of the Byzantine practice (which had been essentially predicated on geometric and abstract themes, in consonance with the 


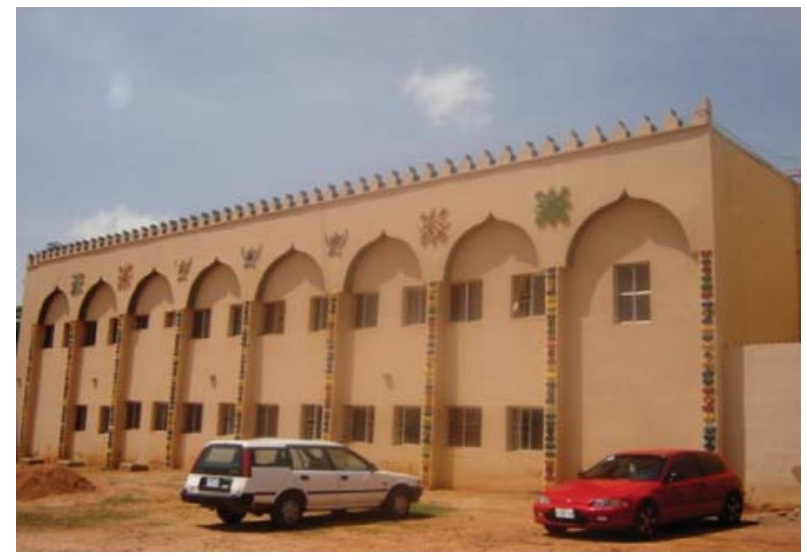

Figure 26: Back elevation of the Emir of Zaria's Palace complex, Zaria (2009).

Islamic abhorrence of attempting to artistically reproduce nature) became the model for such artistic interventions; the most common motif was the arabesque, of Islamic antecedents (see Fig. 26).

\subsection{The post-amalgamation colonial scene}

With the amalgamation of the Northern and Southern Protectorates in 1914 (and the creation of Nigeria), officially, the British were fully in charge of the whole country. Their direct impact on the north resulted in educational and economic policies (among others), which left tangible evidence in the region - albeit much less than in the south. The Western-style schools introduced all over the country were viewed with suspicion in the north, while their koranic ones continued to enjoy wide appeal. Girl-child education (of whatever sort), initially, was not countenanced here; in the south, any initial cultural resistance to the female emancipation prospects of such education, was more readily overcome.

Of continued economic interest to the colonialists, were agricultural and mining enterprises. The north supplied cotton, groundnuts, bauxite, and tin, while the south supplied coal, timber, rubber, palm oil, and cocoa, among others. Several industries had already been set up which saw these raw materials at least through the initial stages of refinement, making it more convenient for them to be shipped abroad.

With respect to the physical environment, British planning, engineering, and general design principles - entrenched in PWD (Public Works Department) practices - continued to guide colonial physical development, and to provide prototypes to pattern local building enterprises on, after independence. Post- independence (and as a concession to social adjustment and acceptance of the erstwhile-colonized as cultural equals), it was not uncommon for the lingering British presence to endorse certain traditional expressions and practices deemed worthy. A case in point is the recourse to traditional mural decoration of the British Council building in Kano, in which though techniques, expertise, and materials were 'local' (i.e. based on Hausa practices), there was an interesting departure from the traditional, in terms of general subject-matter (motif) (see Figs. 27 and 28). 


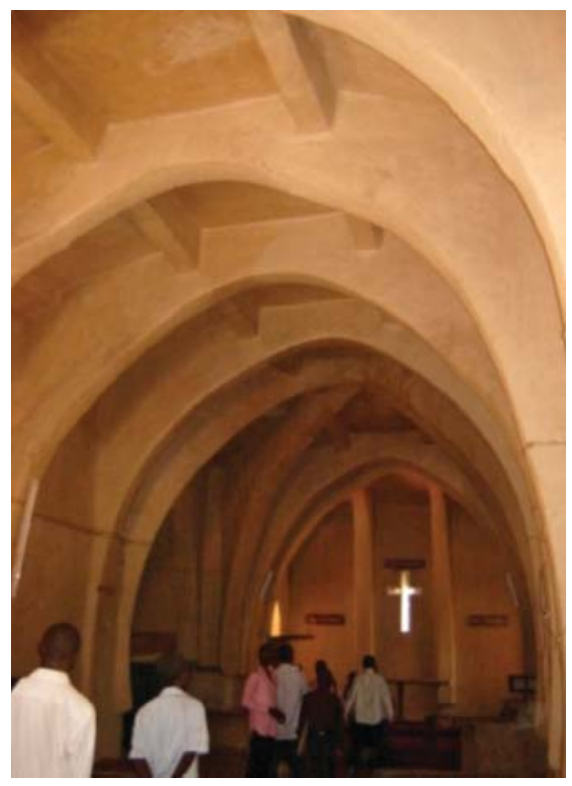

Figure 27: St. Bartholomew's Anglican Church, Wusasa, Zaria, using traditional Hausa roof-vaulting. Evidence of the existence of Hausa Christians.

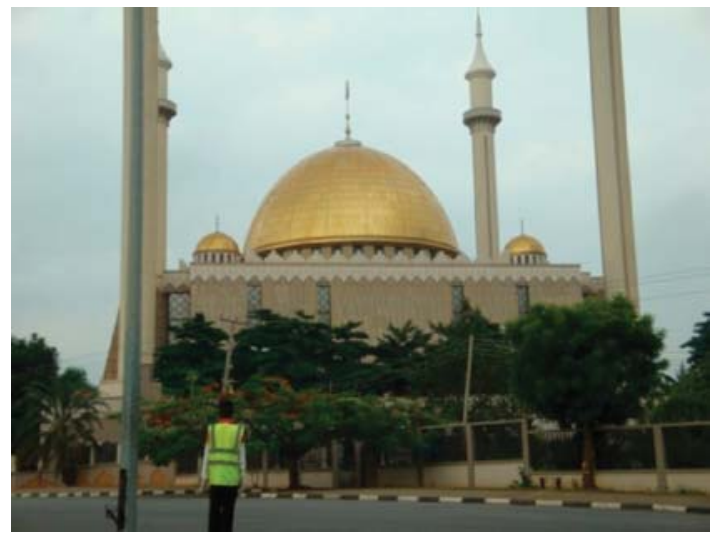

Figure 28: Central Mosque, Abuja. It has a dominant dome flanked by two subsidiary ones and four minarets. Wuse-Garki District (2010).

\section{CULTURE-BASED TRANSFORMATIONS: THE NIGERIAN EXPERIENCE}

To speculate as to whether British colonization had a lasting impact on Nigeria would be a subtle attempt to deny the obvious. Between 1861 (when Lagos was officially ceded to the British Crown and started playing an important role in Anglo-Nigerian relations) and 1960 when the country attained independence, there was progressive 'anglicizing' of the Nigerian psyche and physical environment. Early obvious trans-cultural imports included the English language (as the nation's lingua franca), European-style dress and cuisine, Western education, non-indigenous religious observances, 
and non-traditional building practices. These various 'non-traditional cultures' surreptitiously infiltrated the local institutions and practices, resulting over the intervening decades, in a local culture which though far from being homogeneous, provided a common base for the various ethnicities to overlay their peculiar identities. Today, with the globalization trend, this common given start-off platform is no longer just pro-British (or Western) but more pro-universal. At the level of nationstates, amenities like potable water, electricity, formal education (at all levels), healthcare delivery, information and communication technology (ICT) - all fall-outs of industrialization - are, generally, a universal given.

To adequately do justice to the level of internalization and subsequent ethnic personalization of this 'global' culture, it will be necessary to look again at some Nigerian cultural groups. Even with ethnicities that will not be cited, the reality on ground is that the indigenous cultures have been significantly impacted upon, are still transforming, and have extrapolated the process to the physical environment, in noticeable and tangible ways. Even in the northern parts of the country, despite the strong Islamic under-structure, this globalizing impact is nonetheless clearly discernible; to the south, it represents a strong substructure upon which decisions are consciously taken to re-define an identity - either to move 'forward' in totally embracing the process, or to subtly adjust, such that the trado-cultural values and institutions are not totally subsumed.

\subsection{Contemporary northern Nigeria}

Despite Nigeria officially being a secular state, in the northern region of the country, the Islamic influence is all-pervading. It has continued to affect language, dress, and general social customs to the extent that, to the outsider, the average northerner is assumed to be a Muslim - based on these verbal and non-verbal communications. The more global indices of cultural diffusion (particularly those harking back to colonization) are manifest in the fair abundance of non-koranic schools (right up to tertiary level), cosmopolitan commodities (hardware, household and other goods), and services. Even though the Hausa language is the local lingua franca, English is still the official mode of verbal and written communication, and a smattering of it is known in most the rural areas.

\subsubsection{The built environment}

Expressions of builtform more boldly typify Islamic (Arabic) practices. According to Hakim and Ahmed [23], the Prophet Mohammed supported sedentary existence (actively discouraging people from 'reverting to a Bedouin lifestyle'), and considered the building and upkeep of fortified settlements 'a virtue'. As such, today, large settlements of Hausa and other northern ethnicities have long become the norm. In fact, many large and flourishing cities (such as Sokoto and Yola; Fig. 9) are to be identified with the hitherto traditionally pastoralist Fulani; such 'settled' Fulani are (derisively) referred to as Fulanin gida ('town Fulani') by their cattle-rearing kinsfolk. In their residences and general lifestyle, urban Fulani do not differ significantly from their Hausa counterparts; the common, over-riding culture-definer is Islam. Even so-called pastoralist Fulani, by virtue of proximity to oasis of modernization (such as Federal Government colleges), are no longer totally nomadic, and have regular recourse to such amenities as piped water, and other modern conveniences like motorcycles - courtesy of such strategic positioning. Using Zaria as a case-study, Hakim and Ahmed have been able to prove that despite its 'modernizing' tendencies (such as the presence of several tertiary educational institutions, including a university), the city has developed a complex urbanity, evolved essentially based on principles embedded in ancient traditional customs and Islamic values [24]. In addition to even humble residences featuring pointed arches (among other distinguishing elements), mosques are not only a common feature of all neighborhoods, but in major towns vie with one 


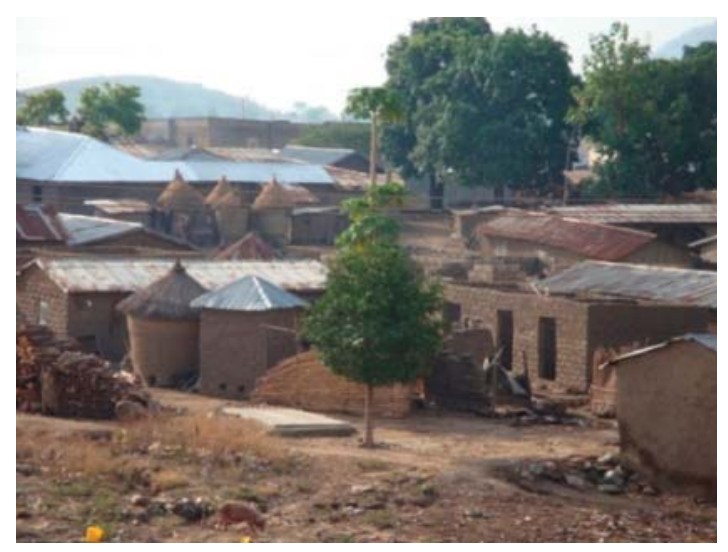

Figure 29: A Gwari village on the outskirts of Abuja. Buildings still of adobe, but roofed with corrugated metal sheets. Notice granaries background and foreground, some now rectilinear and sheet-roofed (2010).

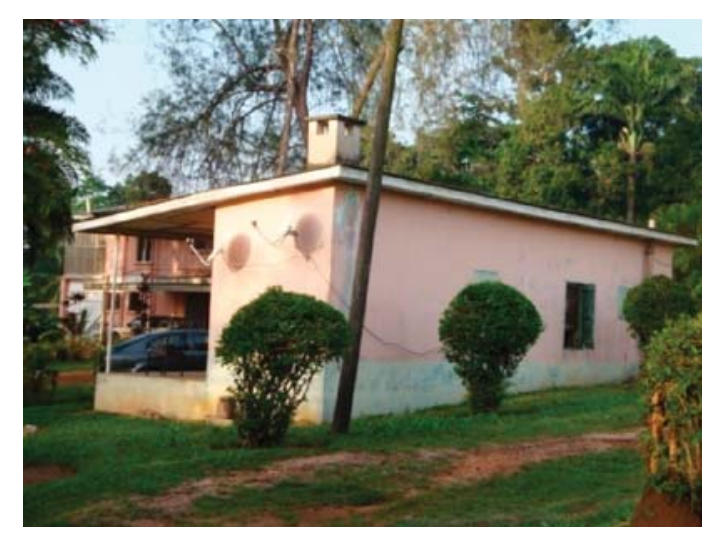

Figure 30: Boys' quarters in Staff Quarters, OAU, Ile-Ife. Apart from cable-network dishes, it has retained its original form (2010).

another in ornateness and general grandeur (Fig. 29). Generally noticeable too, among elite Hausa (and most northerners), the traditional floor plans of the domestic unit have been significantly adjusted to cater for a more varied - more cosmopolitan - social circle.

Despite the preponderance of buildings bearing the unmistakable stamp of the Arabic influence (Fig. 30), and a general espousal of 'high' expressions of virtually all shades of architectural expressions in the cities of northern Nigeria (especially the capital, Abuja), it is noteworthy to state that they exist (sometimes, literally) side by side with more hybrid - though essentially vernacular buildings. For instance, right on the outskirts of the nation's capital, local Gwari communities continue their existence in relative un-sophistication, making use of building practices and forms that have not significantly altered from their more traditional past. In the spirit of global urban practices, such settlements are not totally devoid of modern amenities (e.g. electricity and GSM telephony) - as is the case with the village in Fig. 31. 


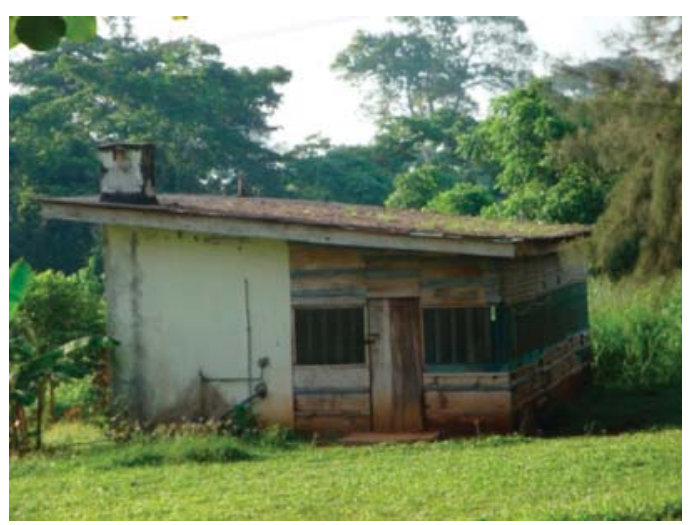

Figure 31: Another first-generation boys' quarters prototype, in the OAU Staff Quarters. The veranda has been built up (2010).

\subsection{Contemporary southern Nigeria}

As previously posited, southern Nigeria generally accommodated the colonial influence more comprehensively than the north. It would not be far-fetched to say that the relative ease with which southerners embraced Christianity, greatly facilitated the advance and eventual entrenchment of Western practices in the south; on grounds of missionary/evangelical success alone, the south was a more favorable location for the colonialists to settle and institutionalize commerce, formal education, and general political administration. As such, there is a greater proliferation of material legacies of the colonial occupation in the south of the country, than in the north.

Here in the south, the generality of people are more pre-disposed to seek Western ties (unlike what routinely obtains in the north), when bi-lateral trade, overseas education, or general international collaborations are being considered; however, here too in recent times, oil-wealth has made the Middle East an inviting and generally preferred business destination; in the north, the first option has spontaneously and consistently been pro-Islamic collaborations - the nation's British colonial history not with standing.

\subsubsection{The southern builtscape}

Apart from the actual buildings of colonial origin dotting the landscape, there is an observable, generally pro-Western orientation in the unfolding development of the built environment. Though there are many individual projects where a deliberate Islamic flavor is given to a building scheme (either in response to a client's brief or to reflect the architect's religious or design bias), they constitute pockets of uncharacteristic developments in the south. With the virtually no-holds-barred approach of Post-Modernism, the architectural scene is typified by an assortment of styles and hybrid expressions, in which the general advances of construction and materials technology play a signal role. One of the enduring archetypal legacies of the colonial era is the 'boys' quarters' phenomenon. Today, many a domestic building project starts off with the 'boys' quarters' - as temporary residence while the resources to build the grander 'main house' are being amassed; also, even when the means to start construction of the main house in the residential premises is available, the boys' quarters is invariably a part of the complex - as detached quarters for dependants or tenants (who keep the premises lived-in and psychologically secure, in the event of the house-owners' absence; [25]). In the Obafemi Awolowo University's staff housing scheme in Ile-Ife (embarked upon in the late 


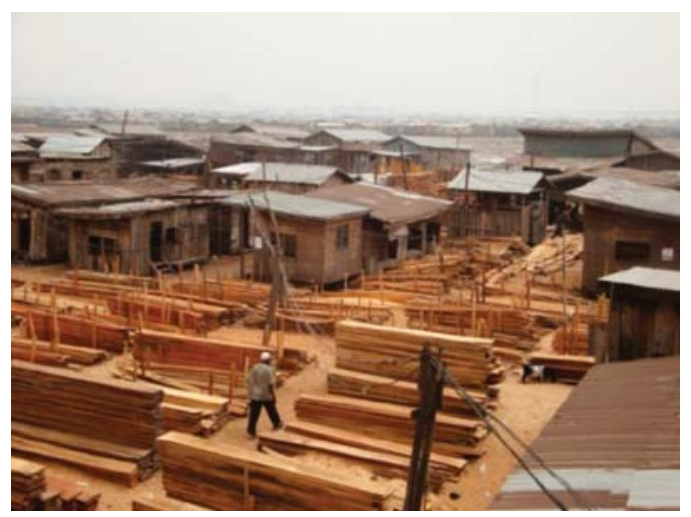

Figure 32: Makoko, Lagos. Sawn planks are the backbone of the community's economy, are stacked in readiness for sale. Note the electricity cables (2010).

1960s), the boys' quarters was an automatic feature of the spatial provision. Even after its contextual utility had been debunked, it is interesting to note that the earliest prototypes still retained the chimney! Figures 20 and 21 show typical trends vis-à-vis the 'boys' quarters', particularly the tendency to 'upgrade' and extend.

High urban-style architecture more correctly characterizes the larger towns and cities of the south. As with the north, these oases of high urbanization are often juxtaposed with less-pretentious developments expressing the folk practices in building (un-embarrassed and refusing to be intimidated), standing proximal to them. Makoko (an extensive squatter settlement in Lagos), typifies the low-end of such built environments which may not, at first glance, impress one as remotely embodying any attributes of modern living. A riverine community of Ijaw-speaking people, it features shack-homes and other temporary structures supported above the high tides of the Lagos creeks and lagoons. Apart from being traditionally fishermen, the people essentially derive their livelihood from logging and planking activities - enterprises which have made the availability of electricity non-negotiable. Despite the generally squalid setting - and near-decrepit appearance of most of the structures - virtually all homes boast of modern appliances like electric fans, radios, CD players, and television sets; some have refrigeration and freezing units. In the compositional /constructional expressions of the various living spaces, an interesting historical commentary is being relayed: the array of building materials not only talks of options; more significantly, it defines the historical progression in the evolution of the typology. From the earliest expressions in cane construction, one can trace the move to sawn timber planks, and more latterly, to plywood and sheet metal. This, however, is not to say that the progression automatically correlates with the chronological age of the respective buildings (see Figs 32 and 33).

Some of the ongoing architectural 'experiments' (typifying the previously expressed predisposition to re-contextualize the 'traditional' to craft an acceptable contemporary identity that harnesses the advantages of the essentials of cultural experiences to date), will be captured in a few brief case studies. Though by no means representative or necessarily portraying a widespread trend, they are, nevertheless, useful in conveying the essence of the builtscape still being very much in flux. In the Middle Belt, the traditional use of adobe and thatch among the Tiv, in Benue State, is being adapted to create contemporary built-form. Earth, molded into local brick-sizes, is fired in traditional kilns and used for archetypes as diverse as modern homes, churches, and small-scale, suburban hotels and eateries (Fig. 34). 


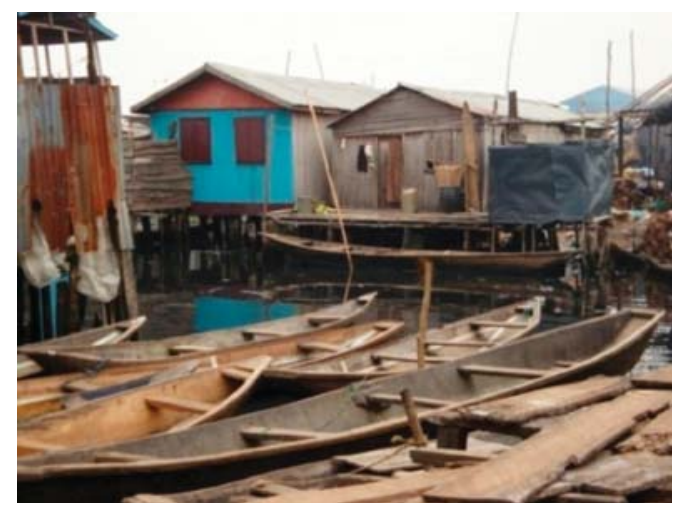

Figure 33: Makoko. Shacks of cane, on timber platforms above the water. Notice enclosures (conveniences), of vinyl and metal cladding, respectively.

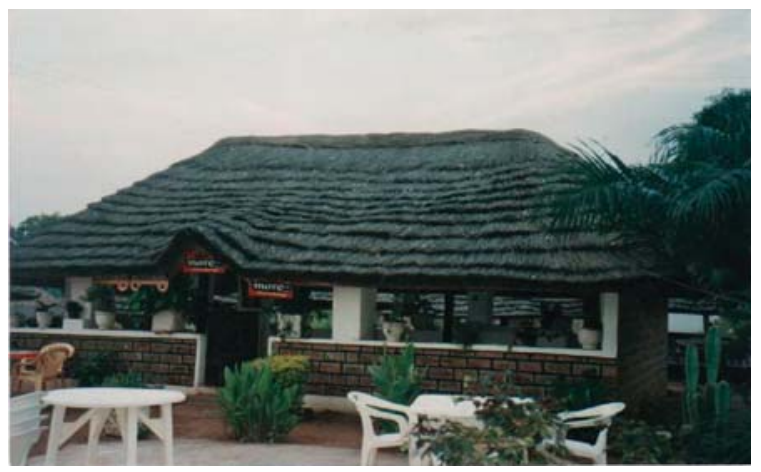

Figure 34: Bush Bar Restaurant, Makurdi; built of fired brick and a traditional-style thatch roof.

The Bini (a very culture-sensitive people) are also integrating age-long building practices and culturally symbolic art icons in their contemporary interpretations of builtform. Additionally, architectural work by professionals in Yoruba-land seeking to revive the complementary art in building tradition of the high vernacular building culture, are some cases in point.

As previously explained, despite the general acceptance of the Christian faith among the Bini, a significant number of the populace still has recourse to traditional deities and forms of spiritual intervention. A middle-of-the-road course seems to be the one being charted by a religious movement that has attempted to harmonize both forms of worship, providing a unique building - neither shrine nor church, in the classical sense - in which devotees' worship can take place. This sanctuary (ambitiously termed a cathedral) articulates the peculiarities of Bini traditional architecture (redearth building, with horizontal grooving), combining these with equally traditional external features of church architecture (such as pointed-arch window openings and glazing). In the wall texturing, even the braid (more a feature of wood sculpting) has been re-visited. The window type is a combination of very modern tinted glass in aluminium sliding frames, and the colonial slanting wooden-slatted jalousie, used here like fan lights. These pseudo fan lights are stylishly pointed - to mimic the Gothic pointed arch; in their permanently open position, they ensure inflow of air, even 

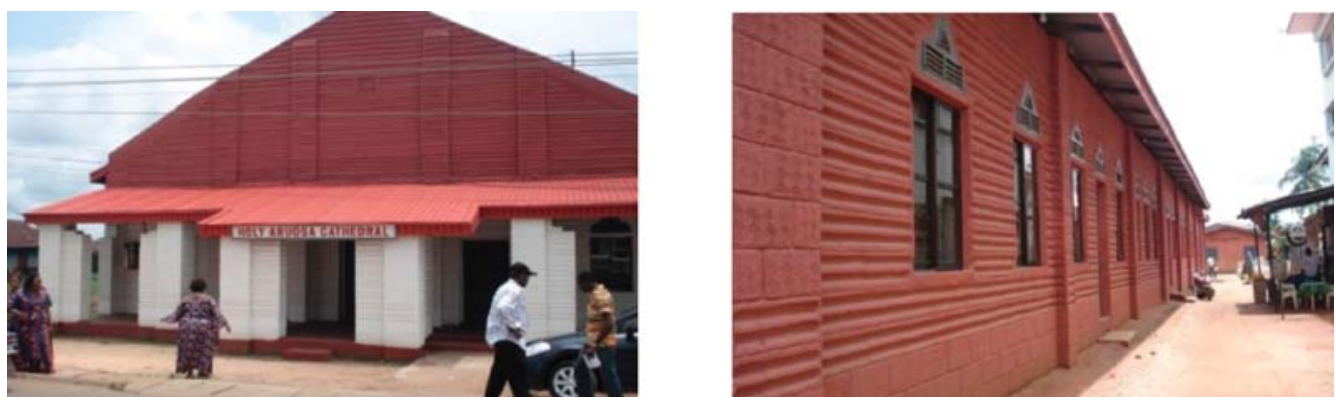

Figure 35: Holy Aruosa Cathedral, Benin City. Left, masonry pillars and gable end-wall typify traditional mortar-fluting. Right, view of the side, from the front toward the rear. Notice the braid motif, extreme left; also, the combination of window types (2009).

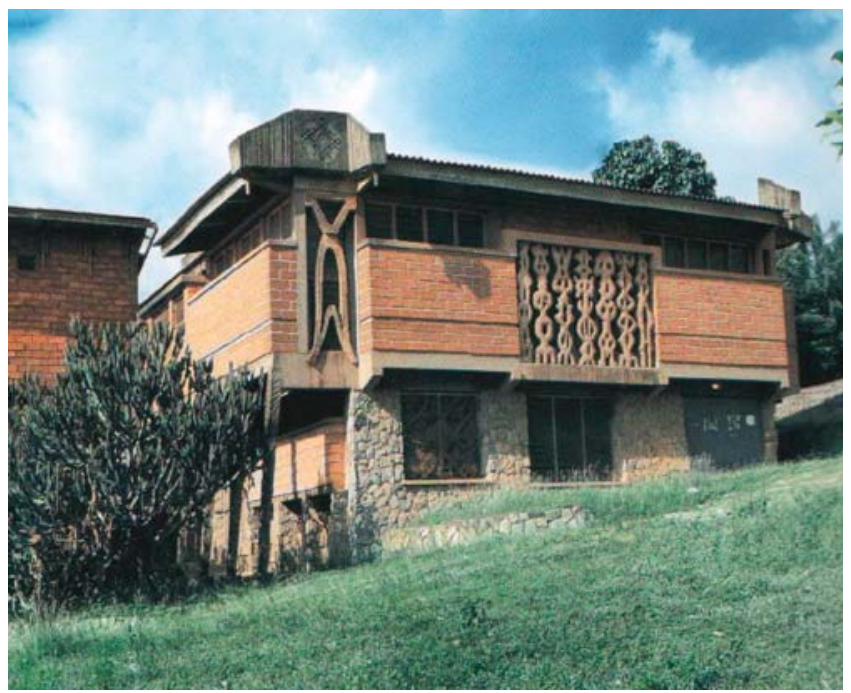

Figure 36: Demas Nwoko's New Culture Studio, Mokola, Ibadan (Godwin and Culture Hopwood, 2007).

when the main windows are shut (Fig. 35). Another example of an attempt to retain traditional expressions while adopting a pro-Western articulation of space and general building can be seen in the modern extension to the $\mathrm{Oba}$ of Benin's palace. Here, the building façade integrates various insignia of Bini royalty, expressed as ornamental metalwork in the burglar-proofing of the reception lobby; in addition to this, the characteristic horizontal fluting is also on display.

The Brazilian building practices spawned a long-lasting tradition of integrating art with architecture. Unfortunately, not only has the practice waned, even the actual physical legacies of this culture (which should have provided authentic evidence of that phase in the nation's architectural evolution) are either decrepit or have totally collapsed (or been demolished), due to lack of understanding of their heritage worth and consequent neglect. A few individuals - scattered in various locations of southern Nigeria - concerned about the trend, are producing architecture to recall this dying tradition and re-contextualize it. Notable among them is Demas Nwoko, a fully trained Painter-Sculptor, who started off in life wanting to be an architect. Nwoko gave up his ambition to study architecture at the Ahmadu Bello University, Zaria, when he discovered 'architecture was taught with no art 
content' [26]. Today, he describes himself as an 'Artist-Designer' [27] and despite this initial disenchantment with architectural study, Nwoko has produced unique (and internationally acclaimed), culturally sensitive architecture in Ibadan, Benin and other parts of southwestern Nigeria. His forte is designing for climatic realities (particularly ensuring sustainable, low-energy designs predicated on traditional models), while spontaneously harnessing art-in-the-round. To his credit, his architectural repertoire features several churches, lecture theatres, cultural centers and private homes, among others (see Figs 36 and 37). In quite a different way, the author is engaged in experimenting with re-contextualizing ornamental elements typical of the high vernacular architectural past. Specifically, she is re-introducing carved fascias and ornamental timber balustrades and partitions in stately homes and church designs. (Over time, metalwork had replaced timber balusters and newels, and screen partitions were no longer fashionable). Figs. 38 and 39 showcase samples of Osasona's work.

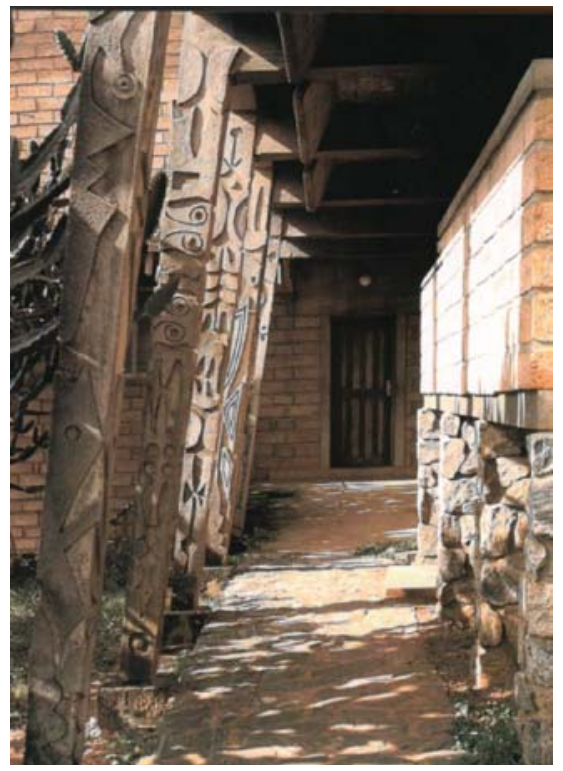

Figure 37: Semi-enclosed walkway in the New Studio complex.

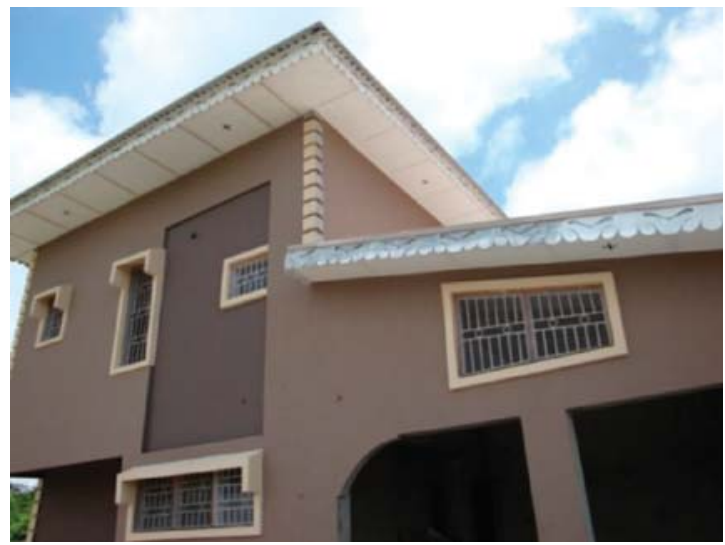

Figure 38: Decorative fascia boards in Shalom Villa, Ile-Ife; painting still ongoing (2009). 


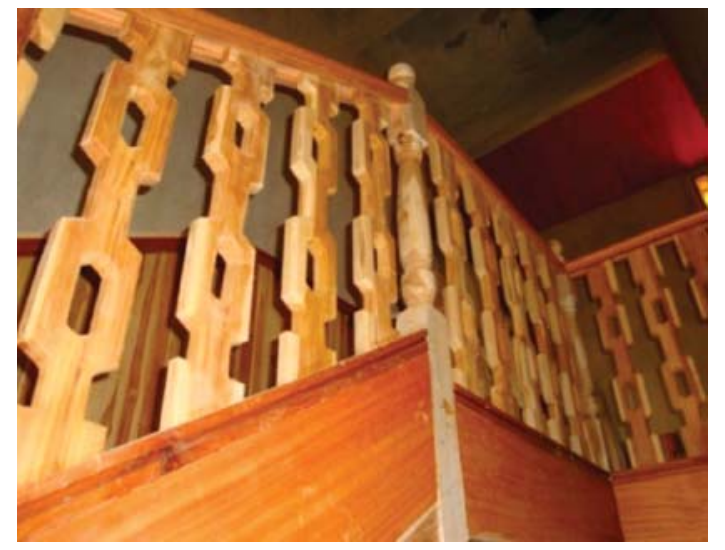

Figure 39: Timber paneling and sculpted balustrade of staircase in Shalom Villa (2008).

\section{PLANNING AND SUSTAINABLE DEVELOPMENT ISSUES}

In keeping with global trends, Nigeria has engaged itself, in the last thirty-five years, with urban and regional planning schemes; expectedly, all such endeavors have produced housing (the thrust of most being mass-housing - or 'low-cost' housing, as locally termed). In an effort to de-congest (and generally sanitize) Lagos, the political and administrative capital of the nation was moved to Abuja (progressively between 1976 and 1988). However, Lagos, till date, remains the nation's commercial nerve center. More recently - particularly with Lagos still continuing to grow - the general workability of 'mega cities' has become a front-burner policy issue. Currently, the Lagos State government is fine-tuning logistics for transforming Lagos metropolis into a mega city, along internationally acceptable lines. The Rivers and Bornu State governments are also presently engaged in massive city upgrading schemes, geared at producing models of cosmopolitan development, as a paradigm for general environmental upgrading and rational urban growth.

With the emergence of Abuja as the new Federal capital, the city has served as an arena for showcasing the highest and most current in architectural expressions. These architectural 'models' depict the peak in hi-tech, metaphor, and general modernist/post-modernist expressions; the city is a veritable pot-pourri of building vocabularies.

Globally, sustainability is currently a topical issue. However, in Nigeria - and despite the potentials of abundant solar energy - even the harnessing of natural day-lighting for power-generation, is still in its infancy. To their credit, several state capitals (Lagos, Ibadan, Port Harcourt, Maiduguri, and Ado-Ekiti, among such) have solar-powered street lighting; however, even in these instances, its use is not all-encompassing. The equally abundant rain water is only being harvested at the level of individual households employing roof-gutters (rhones); the government is yet to evolve a policy that encourages strategies to initiate rain-water harvesting schemes - not to talk of retrofitting vis-à-vis existing projects. Preferences in building-material specification generally favor the now popularized sandcrete block and concrete, widely available all over the country. Since the 1970s (with the establishment of such research centers as the French Center for Teaching and Documentation, CFTD in Jos; the Nigerian Building and Road Research Institute, NBRRI, in Ota, etc.), investigations into alternative, locally available, cheaper - and hence more sustainable - building materials have been ongoing; however, the various researches are yet to noticeably and positively impact the nation's construction culture. Wood technology - that could have been predicated on the nation's abundant 
forest reserves - has not advanced timber as a building-material alternative, while recycling of building materials is not practiced locally on any appreciable scale. Building construction and general site procedures remain conventional - not necessarily sustainability conscious. By and large, it would appear that the nation, still grappling with fundamental political and general administrative issues, is yet to come to terms with the demands of sustainable development.

\section{CONCLUSION}

Culture has been shown to be all-encompassing, in terms of being composed of elements from every facet of the human experience. It is seen as having a tendency to be subject to transformation and, as such, being non-static. One of the conditioners of culture is socio-political subjugation, exemplified in the African experience by European colonization. With the Nigerian cultural scenario overturned by British occupation - giving rise to many institutions (social, economic, political and physical) the nation has had to both adopt and adapt, to make general progress. Here, the north-south dichotomy has proved a significant standpoint from which to assess the nation's response to the colonization intervention, the immediate fall-outs thereof, and the subsequent re-defining of the totality of Nigerian culture that is still ongoing. Many cultural interest groups (spanning the wide ethnographic spectrum of the nation), out of concerns of 'cultural identity erosion', are spearheading revivals of traditional customs. Such concerted efforts include attempts at re-popularizing native attire, institutionalizing local dialects in school curricula, and sponsoring 'cultural festivals' - all in a bid to achieve cultural sustainability.

Table 1: Analysis of Nigerian house-forms in historical context.

\begin{tabular}{|c|c|c|c|}
\hline $\begin{array}{l}\text { Major } \\
\text { Nigerian } \\
\text { ethnic groups }\end{array}$ & Traditional house-form & $\begin{array}{c}\text { Major cultural/builtform } \\
\text { conditioners }\end{array}$ & Present-day/builtform \\
\hline Hausa & $\begin{array}{l}\text { Rectilinear adobe units, } \\
\text { shallow-domed with } \\
\text { earth, linked by adobe } \\
\text { fence-wall; ancillary } \\
\text { granaries; minimal geo- } \\
\text { metric mural decoration }\end{array}$ & Islam & $\begin{array}{l}\text { Essentially still traditional } \\
\text { in villages; various modern } \\
\text { expressions, but still condi- } \\
\text { tioned by Islamic require- } \\
\text { ments }\end{array}$ \\
\hline Fulani & $\begin{array}{l}\text { Discrete, circular units } \\
\text { of vegetable matter and } \\
\text { hides and skins, with } \\
\text { roof and wall-cladding } \\
\text { continuous; granaries }\end{array}$ & Islam/occupation & $\begin{array}{l}\text { Nomadic Fulani still use } \\
\text { impermanent structures; } \\
\text { urban sedentary Fulani build } \\
\text { rectilinear masonry structures, } \\
\text { with modern sheet roofs }\end{array}$ \\
\hline Tiv & $\begin{array}{l}\text { Circular cob, discrete } \\
\text { buildings with shal- } \\
\text { low courses; very steep } \\
\text { thatch roofs; granaries } \\
\text { of earth or fibers; mini- } \\
\text { mal multi-theme mural } \\
\text { decoration }\end{array}$ & British colonization & $\begin{array}{l}\text { Generally, rectilinear masonry } \\
\text { houses; where used, circular } \\
\text { or rectilinear earth gra- } \\
\text { naries; re-popularizing of } \\
\text { traditional expressions in } \\
\text { urban contexts }\end{array}$ \\
\hline
\end{tabular}


Table 1: Continued

\begin{tabular}{|c|c|c|c|}
\hline $\begin{array}{l}\text { Major } \\
\text { Nigerian } \\
\text { ethnic groups }\end{array}$ & Traditional house-form & $\begin{array}{c}\text { Major cultural/builtform } \\
\text { conditioners }\end{array}$ & Present-day/builtform \\
\hline (1) & $\begin{array}{l}\text { Circular adobe/cob } \\
\text { discrete buildings, with } \\
\text { thatched roofs; grana- } \\
\text { ries of earth or fibers; } \\
\text { coupling of some units } \\
\text { based on matri-linear } \\
\text { relations; heavy multi- } \\
\text { theme mural decoration }\end{array}$ & $\begin{array}{l}\text { Islam/ British coloniza- } \\
\text { tion }\end{array}$ & $\begin{array}{l}\text { Generally, rectilinear masonry } \\
\text { houses; where used, circular } \\
\text { or rectilinear earth grana- } \\
\text { ries; modern urban expres- } \\
\text { sions conditioned by Islamic } \\
\text { requirements }\end{array}$ \\
\hline Yoruba & $\begin{array}{l}\text { Multi-cell adobe/cob, } \\
\text { rectilinear compound } \\
\text { houses, with multiple } \\
\text { impluvium-courtyards; } \\
\text { rectilinear adobe or fiber } \\
\text { barns as needed; masonry } \\
\text { perimeter fencing part of } \\
\text { building fabric }\end{array}$ & British colonization & $\begin{array}{l}\text { Rectilinear houses; highly } \\
\text { westernized contextual- } \\
\text { izing of modern-day spatial } \\
\text { requirements, with a varied } \\
\text { landscape significantly fea- } \\
\text { turing popular vernacular }\end{array}$ \\
\hline Bini (Edo) & $\begin{array}{l}\text { Multi-cell adobe/ cob, } \\
\text { rectilinear compound } \\
\text { houses, with multiple } \\
\text { impluvium-courtyards; } \\
\text { rectilinear adobe or } \\
\text { fiber barns as needed; } \\
\text { masonry perimeter } \\
\text { fencing part of build- } \\
\text { ing fabric; spontaneous } \\
\text { featural decoration }\end{array}$ & $\begin{array}{l}\text { Traditional worship/ } \\
\text { British colonization }\end{array}$ & $\begin{array}{l}\text { Rectilinear houses; highly } \\
\text { westernized contextual- } \\
\text { izing of modern-day spatial } \\
\text { requirements; courtyard } \\
\text { articulation still popular; } \\
\text { formal/ general typological } \\
\text { experimentations noticeably } \\
\text { ongoing }\end{array}$ \\
\hline Riverine Ijaws & $\begin{array}{l}\text { VSkeletal, lightweight } \\
\text { timber/ vegetable } \\
\text { structures on a rec- } \\
\text { tilinear plan; some } \\
\text { buildings of masonry } \\
\text { where terra firma } \\
\text { available }\end{array}$ & $\begin{array}{l}\text { Slave Trade/ British } \\
\text { colonization/ commu- } \\
\text { nity occupation }\end{array}$ & $\begin{array}{l}\text { Still essentially skeletal/ } \\
\text { lightweight, but featuring } \\
\text { modern cladding materials; } \\
\text { more pretentious, pro- } \\
\text { Western structures in larger } \\
\text { communities with greater } \\
\text { expanse of landmass }\end{array}$ \\
\hline Igbo & $\begin{array}{l}\text { Rectilinear, discrete cob/ } \\
\text { wattle-and-daub houses; } \\
\text { rectilinear adobe or fiber } \\
\text { barns as needed; orna- } \\
\text { mentation of furniture } \\
\text { and symbolic features; } \\
\text { independent masonry } \\
\text { fence }\end{array}$ & British colonization & $\begin{array}{l}\text { Owing to serious constraints } \\
\text { on land (quantitative/ and } \\
\text { qualitative), multi-apartment } \\
\text { tenement housing greatly } \\
\text { favored in urban centers; } \\
\text { highly-westernized expressions } \\
\text { limited in local Igbo metropo- } \\
\text { lises; vernacular typologies } \\
\text { very popular in villages }\end{array}$ \\
\hline
\end{tabular}


With respect to the built environment, it has been established that the country was greatly impacted by the British presence, with physical legacies providing visual evidence of the occupation. These have served as reference-points for further articulation of physical development. Presently (and particularly in the south), there is an ongoing revival of colonial-style buildings, with respect to residential, hotel, and recreational architecture. Side by side with this trend, is the flurry of new-town planning and implementation, and general urban-center upgrading. In the midst of all this, individuals and groups are re-defining contextual vernacular architecture, in a bid for 'local content' not to be altogether lost. (Table 1 below provides a historical taxonomy of the major house-forms across the country).

In the light of the scenario described (vis-à-vis the built environment), it is obvious that the various trends already underway in the country, will continue for some time to come. As more and more prototypes of the various pioneering/revivalist efforts are available within the building-environment fabric, they will either inspire for greater institutionalization, or provoke other experiments that seek to address areas of perceived inadequacy. Certainly, with the dangers of 'global warming' increasingly being impressed upon all regions of the world, Nigeria will have no choice but to take the issue of sustainable building and general development, seriously.

\section{REFERENCES}

[1] Saad, H.T., The role of individual creativity in traditional African art: the gwani (genius) among master-builders of Hausaland. Nigeria Magazine, 53(4), pp. 1-12, 1985.

[2] Hakim, S. \& Ahmed, Z., Rules for the built environment in 19th century northern Nigeria. Journal of Architectural and Planning Research, 23(1), pp. 1-26, 2006.

[3] Dmochowski, Z.R., An Introduction to Nigerian Traditional Architecture, 2, Ethnographica Ltd: London, p. 4.57, 1990.

[4] Bohannan, L. \& Bohannan, P., The Tiv of Central Nigeria, International African Institute: London, p. 15, 1953.

[5] Denyer, S., African Traditional Architecture, Heinemann Educational Books Ltd.: London, p. 144, 1978.

[6] Dmochowski, Z.R., An Introduction To Nigerian Traditional Architecture, 2, Ethnographica Ltd: London, p. 3.27, 1990.

[7] Nadel, S.F., A Black Byzantium: The Kingdom of Nupe in Nigeria, University Press: London, 1961.

[8] Umeukeje, T.A., Cultural Impact of the Igbo in History, Local Historical Essay Series, No. 1, Enugu, 1972.

[9] Cole, H.M. \& Aniakor, C.C., Igbo Arts: Community and Cosmos, Museum of Cultural History, UCLA: Los Angeles, p. 64, 1984.

[10] Dmochowski, Z.R., An Introduction To Nigerian Traditional Architecture, 3, Ethnographica Ltd: London, pp. 27, 30 \& 146, 1990.

[11] Cole, H.M. \& Aniakor, C.C., Igbo Arts: Community and Cosmos, Museum of Cultural History, UCLA: Los Angeles, p. 68, 1984.

[12] Agbontaen, K.A., The Impluvium-courtyard (oto-eghodo) in Indigenous Benin Architecture. The Nigerian Field, 61(1 \& 2), p. 60, 1996.

[13] Dmochowski, Z.R., An Introduction To Nigerian Traditional Architecture, 2, Ethnographica Ltd: London, p. 1.33, 1990.

[14] Obateru, O.I., The Yoruba City in History: 11th Century to the Present, Penthouse Publications Nigeria: Ibadan, pp. 217-218, 2006.

[15] Osasona, C.O. \& Hyland, A.D.C., Colonial Architecture in Ile-Ife, Nigeria, Bookbuilders, Editions Africa: Ibadan, p. 45, 2006.

[16] Olomola, S., Ife before Oduduwa (Chapter 2). The Cradle of a Race: Ife from the Beginning to 1980, ed. I.A. Akinjogbin, Sunray Publications Ltd.: Port Harcourt, p. 54, 1992. 
[17] Anquandah, K.I., Castles and Forts of Ghana, Atalante: Paris, 1999.

[18] Osasona, C.O. \& Hyland, A.D.C., Colonial Architecture in Ile-Ife, Nigeria, Bookbuilders, Editions Africa: Ibadan, p. 66, 2006.

[19] Akinsemoyin, K. \& Vaughan-Richards, A., Building Lagos, Pengrail Ltd.: Lagos, p. 20, 1977.

[20] Hallen, B., Afro-Brazilian Mosques in West Africa, MIMAR 29: Architecture in Development, Concept Media Ltd.: Singapore, pp. 16-17, 1988.

[21] Osasona, C.O. \& Hyland, A.D.C., Colonial Architecture in Ile-Ife, Nigeria, Bookbuilders, Editions Africa: Ibadan, p. 4, 2006.

[22] Osasona, C.O., The Symbolic Value of Space and Material in Nigerian Traditional Houseforms, Journal of Environmental Technology, FUTA: Akure, pp. 125-126, 2002.

[23] Hakim, S. \& Ahmed, Z., Rules for the built environment in 19th century northern Nigeria. Journal of Architectural and Planning Research, 23(1), pp. 1-18, 2006.

[24] Hakim, S. \& Ahmed, Z., Rules for the built environment in 19th century northern Nigeria, Journal of Architectural and Planning Research, 23(1), pp. 1-19, 2006.

[25] Osasona, C.O., From Traditional Residential Architecture to the Vernacular: The Nigerian Experience; African Architecture Today Conference Online, p. 13. available at http:www. mudonline.org/aat/2007_documents/AAT_Osasona

[26] Godwin, J. \& Hopwood, G., The Architecture of Demas Nwoko, Farafina: Lagos, p. 17, 2007.

[27] Godwin, J. \& Hopwood, G., The Architecture of Demas Nwoko, Farafina: Lagos, p. 10, 2007. 